\title{
The British state and the Irish rebellion of 1916: an intelligence failure or an failure of response
}

Article

Accepted Version

Sloan, G. (2013) The British state and the Irish rebellion of 1916: an intelligence failure or an failure of response.

Intelligence and National Security, 28 (4). pp. 453-494. ISSN 1743-9019 doi: https://doi.org/10.1080/02684527.2012.735079 Available at https://centaur.reading.ac.uk/25318/

It is advisable to refer to the publisher's version if you intend to cite from the work. See Guidance on citing.

To link to this article DOI: http://dx.doi.org/10.1080/02684527.2012.735079

Publisher: Taylor \& Francis

All outputs in CentAUR are protected by Intellectual Property Rights law, including copyright law. Copyright and IPR is retained by the creators or other copyright holders. Terms and conditions for use of this material are defined in the End User Agreement.

$\underline{\text { www.reading.ac.uk/centaur }}$ 
Central Archive at the University of Reading

Reading's research outputs online 
THE BRITISH STATE AND THE IRISH REBELLION OF 1916:

\section{AN INTELLIGENCE FAILURE OR A FAILURE OF RESPONSE?}

In 1916 the conspirators within the IRB launched a longplanned surprise attack without provocation. Peter Hart, 2002.

The Easter Rising represented - quite apart from anything else - a massive failure for British intelligence in Ireland. Bernard Porter, 1989.

I always thought that I was very ignorant of what was going on in the minds, and in the cellars if you like, of the Dublin population. Augustine Birrell, Chief Secretary of Ireland. Royal Commission on the Rebellion in Ireland, May 1916.

\section{INTRODUCTION}

These three epigraphs illustrate the widely accepted view of the rebellion that took place in Ireland on the $24^{\text {th }}$ April 1916, and the perceived intelligence failure preceded it. Furthermore, historians have passed judgements on two vital contextual aspects of this event. First the overall effectiveness of the intelligence that the British state had access to prior to the 1916 rebellion, and indeed up to 1921, has been characterised as an :'Irish Debacle' ${ }^{1}$.Secondly, the political context and the character of British rule in Ireland, despite the longevity of the Act of Union ,(1800) have been judged as not typical of conditions that pertained in the rest of the United Kingdom: "In 1900 the United Kingdom was 100 years old, and that century had been filled with the various forms of diffused insurgency on the Irish side, countered by a steady stream of repressive legislation on the British side."2

This article will argue that there exists in the literature on the rebellion a lacunae. Specifically with reference to the Royal Navy's signals intelligence unit, Room 40.Although its importance was acknowledged by O'Broin in his seminal on the rebellion. ${ }^{3} \mathrm{He}$ claimed that the Cabinet and that included Birrell were not given access to this unique source of

\footnotetext{
${ }^{1}$ See C Andrew, Secret Service, The Making of the British Intelligence Community, London: Sceptre Books ,1986 p355-372.

${ }^{2}$ C. Townshend, Britain's Civil Wars ,London :Faber and Faber, 1986 p46.

${ }^{3}$ L. O’Broin, Dublin Castle and The 1916 Rising <London :Sidgwick and Jackson,1966 p136-140.
} 
intelligence. ${ }^{4}$ In short this represented a failure of intelligence not a failure of response. It will also be argued that the intelligence institutions of the British state in Ireland functioned in an effective enough manner given the clandestine and conspiratorial nature of the threat. Most of the existing literature supports a teleological narrative of intelligence failure. This is set within a wider political interpretation: "The dominant narrative remains that of the nationalist movement in conflict with British rule."

In order to address this distortion a synthetic approach will be adopted that uses the conceptual approaches derived from Intelligence Studies. It will be argued that the British authorities both in Dublin and London were supplied with timely and accurate intelligence relating to events leading up to the 1916 rebellion. With respect to the latter there is evidence to show that the political head of the Royal Navy, Arthur Balfour, gave a clear warning to the Cabinet of this impending event. :"We knew beforehand that the Revolution in Ireland would start on Easter Monday 1916.and made naval preparations in advance. The Cabinet would not believe the First Lord."'Furthermore, it was the Admiralty staff that conveyed to Downing Street the news of the outbreak of the rebellion in Dublin: "On Easter Monday I told the Duty Captain to keep in touch with the Post Office about the Irish Telegrams and when the DC told me the P.O. had telephoned that the system was blocked ,I telephoned to Downing Street to the PM's Secretary to tell the PM that the rebellion had commenced." ${ }^{, 7}$ There was no failure of intelligence in London. ${ }^{8}$ The extent to which there was one in Dublin will be assessed later in this article. Secondly, there was a failure of response by policy makers to act on this intelligence until it was too late. Finally, this can best be understood by an assessment of the policy assumptions ${ }^{9}$ of the key British decision makers prior to the rebellion. For this approach to be successful a number of related questions need to be addressed. What was the nature of the intelligence institutions upon which the Irish Executive of the British Government depended? Can the failure of response be explained by the manner in which the intelligence was processed? Why

\footnotetext{
${ }^{4}$ Ibid p140.

${ }_{6}^{5}$ P. Hart ,The IRA at War 1916-1923,Oxford :Oxford University Press 2003 p8.

${ }^{6}$ Recollections Vols 1,2, unpublished memoirs of Admiral of the Fleet Sir Henry Oliver, National Maritime Museum, OLV 12,p165.

${ }^{7}$ Ibid p165.

${ }^{8}$ Asquith and Hankey did not receive news of the rebellion until the early hours of the $25^{\text {th }}$ April :"They reached Downing Street on the 12.30am to find the first news of the Easter rebellion awaiting them .Asquith merely said "Well ,that's really something" and went off to bed." S.Roskill, Hankey Man of Secrets Volume 1 1877-1918,London: Collins 1970.p265.

${ }^{9}$ For an incisive contribution to the literature on the relationship between intelligence and policy assumptions see P.R. Pillar, Intelligence and U.S. Foreign Policy, New York :Columbia University Press 2011 pp96-120.
} 
did the decision makers fail to respond to the intelligence warnings until it was too late? Can an assessment be made, in hindsight, of the quality of the intelligence that policy makers were supplied with?

\section{LIVING WITH THE PAST}

Before these questions can be addressed it is important to locate this article in the existing historiography. The 1916 rebellion has received a lot of attention from Irish and British historians. ${ }^{10}$ This event has not simply considered in an insular manner. From the late 1960s the rebellion began to interpreted in a wider context ${ }^{11}$ :"The historiography of this event moved from the narrow (though of course important) focus on conspiracy and martyrdom to the more general question of the rising as an episode in the history of all Ireland and indeed of the British Isles. ${ }^{12}$, More recent scholarship has argued that there is a symbiotic relationship between Irish history and the history of the British Empire: "Modern Irish history unfolded in tandem with the rise, unprecedented expansion and eventual decline of the Empire, and just as Irish history does not make sense without the imperial entanglement ,British imperial history assumes its full dimension if Ireland is included." ${ }^{, 13}$ Understanding the nature of the concerns that the intelligence institutions of the British state had with respect to Ireland, and policy makers reaction to this information, only makes sense if it is understood in a broader context.

Grob -Fitzgibbon has argued that the Irish Revolution covers the years 1912-1922, and must be interpreted as a single historical period. Yet within that period he identifies three schools of thought as to why the British state failed to contain and defeat an insurgency. The first one is referred to as the colony to nation school. This interpretation is characterized in the following way: "The British were defeated in Ireland because of the inevitability of a successful Irish nationalist struggle an effort that had been intensifying for the previous two centuries". 14 The

\footnotetext{
${ }^{10}$ There has been a torrent of books and articles on this subject. They include: F.X. Martin, Eoin MacNeill on the 1916 Rising, Irish Historical Studies ,Vol 11,1966, pp226-71,.T.D. Williams(ed), The Irish Struggle,1916-1926.London: ? 1966,.K.B.Nowlan (ed ),The Making of 1916,Dublin :Stationary Office1969., S.F.,Patrick Pearse and the Politics of Redemption: The Mind of the Easter Rising 1916,Washington DC :?1994, L. O’Broin, Dublin Castle and the 1916 Rising ,London: Sidgwick and Jackson 1966.M.Foy \& B.Barton, The Easter Rising, Stroud Gloucestershire: Sutton Books, 1999 P. Hart, I.R.A. at War 1916-1923.,Oxford:Oxford University Press 2003, K.Jeffery ,The GPO and the Easter Rising ,Dublin: Irish Academic Press 2006,C.Townshend ,Easter 1916 The Irish Rebellion, London :Penguin 2006,F.McGarry, The Rising: Easter 1916,Oxford :Oxford University Press,2010.

${ }^{11}$ See F.X. Martin (ed ),Leaders and the Men of the Easter Rising:Dublin1916,London ?1966

${ }^{12}$ D. George Boyce,1916 ,Interpreting the Rising ,from D. George Boyce and Alan O' Day(eds), The Making of Modern Irish History ,London :Routledge,1986,p165.

${ }^{13}$ K Kenny ,Ireland and the British Empire, Oxford :Oxford University Press, 2004 p1.

${ }^{14}$ B. Grob-Fitzgibbon, Turning points of the Irish Revolution, London: Palgrave Macmillan.2007,p5
} 
second school is termed the repressive-reaction school. The key period is 1916-1921.The failure of the British state in Ireland is viewed in the following way: "British security forces acted with undue force towards the rebels turning them into popular heroes and swaying public opinion away from the British government and onto those who had revolted." 15

The final interpretation is described as the inert-military school.The core of this thesis is that the British Army faced a problem that many military organisations have faced. Understanding the kind of conflict they were involved in, and adapting their methods of operation accordingly: "They(the British)had been schooled in the tactics of mass engagement and trench warfare, where the individual initiative of men and officers counted for very little. They were untrained therefore, for the hit-and-run tactics of the Irish Republican Army." 16

Hart argues that the origins of the rebellion can be seen in the profound changes and destabilization of Ireland's political structure that occurred as a result of the attempt to introduce Home Rule. It resulted in a concatenation of events and forces that ultimately made the rebellion possible: "The creation of the U.V.F., the Liberal government's tolerance of it, and the Irish Party's passivity in the face of both, provided an opportunity for them (dissident nationalists) to enter politics in a paramilitary guise: as the Irish Volunteers, founded in November 1913."17

Most importantly of all this article locates itself in the seminal importance of the First World War. ${ }^{18}$ For the organisers of the rebellion, and the interests of British intelligence and policy makers this event was all defining. Foster argues powerfully that: "The First World War should be seen as one of the most decisive events in modern Irish history. Politically speaking, it temporarily defused the Ulster situation, it put Home Rule on ice, it altered the conditions of military crises in Ireland at a stroke, and it created the rationale for an IRB rebellion. Economically it created a spectacular boom in agricultural prices, and high profits in agriculturally derived industries." ${ }^{, 19}$ Lloyd George went further in that he asserted the pernicious effect of Ireland on Germany's perception of Britain's capacity to deal with a crisis in Europe : "There can be little doubt that the expectation on the Continent that Britain had for the moment sunk so deep in the quagmires of the Irish bog as to be unable to extricate her feet in time to march eastward, was one of the

\footnotetext{
${ }^{15}$ Ibid p8.

${ }^{16}$ Ibid p9.

${ }^{17}$ P. Hart, IRA at War 1916-1923,Oxford :Oxford University Press, 2003 p93.

${ }^{18}$ The best book on this period is K. Jeffery, Ireland and the Great War, Cambridge: Cambridge University Press, 2000.

${ }^{19}$ R.F.Foster ,Modern Ireland 1600-1972,London :Penguin Books ,1989p471.
} 
considerations which encouraged Germany to guarantee Austria unconditional support in her Serbian adventure."20

This conflict had a unique dimension to it that is important to explain. It illuminates the rationale of the interest of the Imperial German Government in Ireland during the First World War. For the first time in the history of warfare there were systematic attempts by military staffs to wage political warfare. The objective was to undermine the opponents war effort by facilitating political unrest or rebellion in elements of their domestic population or in the people's of their empires. Britain was to do this with the Arab Revolt led by T.E. Lawrence. The French were to target the Austro-Hungarian empire. The German effort against its enemies started as propaganda, and it had a number of objectives:" The object of the(German) government's multifaceted propaganda campaign was twofold :to pin down British, French and Russian military forces in counter-insurgency operations behind enemy lines , and to acquire a reputation (both in neutral countries such as the United States and among progressive forces in the enemy camp) as the protector of 'oppressed peoples' and the champion of the rights of maritime and political self determination. ${ }^{, 21}$ This policy evolved to a point whereby it attempted to assist Irish political extremists to stage a rebellion in what was then an integral part of the British state. This raises an additional question, to what extent were there grounds for the British state treating these citizens who took part in the rebellion as if they were external enemies? This question will be examined later in the article.

\section{INTELIGENCE THEORY,THE BRITISH STATE AND IRELAND}

If the First World War is the departure point for this article, it is important to integrate the literature on intelligence theory with the existing historiography on the British state's intelligence organisation in Ireland. O'Halpin provides one model for judging how these structures performed. He has argued that there were three distinct phases in the period from 1914 to $1921 .^{22}$ This article will focus on the first period only. However all three periods had similar challenges: "These phrases are quite distinct, but in each can be seen the same problems of obtaining, organising and evaluating intelligence which characterised the British effort to maintain order and political control in Ireland." ${ }^{23}$ Grob-

\footnotetext{
${ }^{20}$ D. Lloyd George, War Memoirs vol 2,London :Nicholson \&Watson,1933 p694.

${ }^{21}$ W.Keylor ,The Twentieth Century World ,Oxford: Oxford University Press,1992p59.

${ }^{22}$ They were $1914-1916,1916-1918$,and 1918 to 1921. See E.O'Halpin, British Intelligence in Ireland ,1914-1921 from C Andrew and D. Dilks,(eds) The Missing Dimension, Chicago :University of Illinois Press 1984,p54.

${ }^{23}$ Ibid pp54
} 
Fitzgibbon goes a step further and maintains that the three interpretations, that he has outlined, have all got something missing. The key element is intelligence :"In none of these interpretations is the question of what the British did or did not know about the insurgents considered. Intelligence is simply not a variable". In terms of the historiography he agrees with O'Halpin that the nature of the intelligence varied over the nine year period. He maintains that an analysis that has an intelligence focus can do two things: first evaluate its role in British security failure; secondly, it can illuminate turning points in the Irish Revolution. ${ }^{24}$

Before giving a summary of how intelligence structures were organised in Ireland it is important to make some general comments about three themes that form an important context of this article. First what should be the relationship between the armed forces and the police in countering the threat of rebellion?. What do we mean by intelligence failure? Finally, what is the utility of intelligence to governance and war, and how had they evolved by the late nineteenth and early twentieth centuries. With respect to the first question the relationship in a liberal state should be one of mutual support and co-operation. This has been summarised by J.F.C. Fuller: "The maintenance of law and order requires two forces, one mobile and one stable. The mobile force is represented by the police, who do not so much enforce the law as, through their uniforms express it. They move everywhere, and though little is said, they endow peace-lovers with a confidence in security and peace-haters with a fear of punishment. The stable force is the army, which quite rightly, is little seen in public; nevertheless, silently it stands behind the police ever ready to enforce the law when persuasion not to break it fails to impress the lawless. ${ }^{625}$ Another key point was a legal one. Ireland in the two years prior to the rebellion it was subject to, in line with the rest of the United Kingdom, the Defence of the Realm Act .This act gave the government the ability, amongst other things, to introduce statutory martial law if required $^{26}$.Even more pertinent to the Irish rebellion it gave power to military tribunals to try cases of collusion with the enemy: "A charge which the rebels had, by trumpeting in the proclamation of the Republic their 'gallant allies in Europe', openly embraced."27

The need, at the operational level, that the mobile and stable forces have in common with respect to any clandestine organisation is the necessity to divert and penetrate networks. This can only be done by

\footnotetext{
${ }^{24}$ B. Grob -Fitzgibbon, Turning Points in the Irish Revolution, London: Palgrave Macmillan,2007 p10.

${ }^{25}$ J. F. C . Fuller, The Reformation of War, London: Hutchinson 1923 p201.

${ }^{26}$ In March 1915 this act was amended to guarantee a civil trial to British citizens for most breaches of the act. Furthermore, it was under this act that the Irish rebels were tried, not martial law.

${ }^{27}$ C. Townshend, Easter 1916 The Irish Rebellion, London :Penguin Books,2006 p1188.
} 
access to intelligence. Despite this similarity Keith Jeffery maintains the police and the army will use the intelligence gained in different ways: "The emphasis on police methods, which ,if the campaign is successful, must eventually prevail, puts a premium on intelligence, since effective police work depends on good information. But the information which the police need to bring terrorists to justice, and to secure convictions, is often of a different quality from that which military intelligence officers require for purely operational reasons." 28

Secondly, there is the concept of intelligence failure. The Japanese attack on Pearl Harbour is often cited as a classic example of this. Herman claims that it has:" become part of modern political vocabulary." 29 It has been termed "warning failure". This usually precedes a surprise attack that takes place in peacetime and leads to the initiation of war. There is an impressive historical pedigree ${ }^{30}$.It can also be understood as something that all intelligence organisations are vulnerable to: "No matter how well an intelligence service is organised, how sound its tradecraft, how extensive its resources , and how skilful the people who staff it, it will sometimes fail." 31

It is important to differentiate this concept from the idea of a failure of policy response : "Warning without response is useless. 'Warning' is evidence filtered through perception; 'response' is action designed to counter an attack (alert,mobilization, and readiness). The linkage between the two is accurate evaluation and sound judgement, the lack of which is the source of most victims' failures to avoid the avoidable." 32 The relationship between warning and response is not one of binary opposition: "Because warning is a continuum, and because surprise attacks are the end products of prolonged tension rather than genuine bolts-from-the-blue ,decision makers are used to living in an environment of some warning. The concern is how much accumulated warning warrants military reaction that will pose financial, diplomatic, and domestic political costs ${ }^{33}$

\footnotetext{
${ }^{28} \mathrm{~K}$. Jeffery, Intelligence and Counter -Insurgency Operations :Some Reflections on the British Experience,Intelligence and National Security, Vol 2 ,No1, Jan 1987. p119.

${ }^{29}$ M. Herman ,Intelligence Power in Peace and War, Cambridge: Cambridge University Press, 1996 p221.

${ }^{30}$ Herman lists the following: Denmark and Norway in 1940; Pearl Harbour in 1941;Russia in 1941; Korea in 1950 ;Chinese attack in 1962;Czechoslovakia in 1968 ; the Yom Kippur in 1973; the Chinese invasion of Vietnam in 1979; the Falklands in 1982; Kuwait in 1990. See Ibid p221-222.

${ }^{31}$ P.R. Pillar, Intelligence and U.S. Foreign Policy, New York: Columbia University Press,2011p217.

${ }^{32}$ R. K. Betts, Surprise Despite Warning from C. Andrew, R. Aldrich, W. Wark ( eds) Secret Intelligence A Reader Intelligence, London: Routledge 2009 p91.

${ }^{33}$ Ibid. p97.
} 
The arbiter between these two concepts are policy preferences and the assumptions that they are based on. It is the weft and warp of determining whether intelligence warnings have any purchase on policy makers: "The intelligence services may collect and analyse the information in a professional way (although they also have institutional interests) but how that information is used depends on the policy preferences and power relations of politicians and officials. ${ }^{\text {(634 This raises }}$ the question about the policy preferences that were important to the Chief Secretary of Ireland, Augustine Birrell and his civil servants in the period that preceded the rebellion: "The policy to which Birrell introduced Nathan (Under-Secretary, Dublin Castle) was to pave the way for Home Rule and make any other solution of the Irish political problem impossible. Apart from Home Rule measure, he had carried no fewer than fifty-five bills through the House of Commons, dealing with subjects such as land purchase, housing and the National University". ${ }^{35}$

Finally, what is the utility of intelligence to governance and war, and how they evolved by the late nineteenth and early twentieth centuries? Intelligence conceptualised as secret information is as old as government and war itself .In Britain Cabinet government has its origins in an early modern intelligence institution: "The modern British Cabinet has origins in the 'Intelligence Committee' of the Privy Council which existed briefly after $1660 " 36$.In terms of warfare ancient Chinese General Sun Tzu, writing in $400 \mathrm{BC}$, coined one of the most important aphorisms about the utility of intelligence in war: "Now the reason that the enlightened prince and the wise general conquer the enemy whenever they move and their achievements surpass those of ordinary men is foreknowledge. What is foreknowledge cannot be elicited from spirits, nor from gods, nor by analogy with past events, nor from calculations. It must be obtained from men who know the enemy situation." 37

In the nineteenth century the increasing relevance of military and naval intelligence grew as a result of developments in weapons and transport technology. ${ }^{38}$ The tactical and operational implications of these changes increased the opportunity for strategic surprise. The institutional

\footnotetext{
${ }^{34}$ M.J. Smith ,Intelligence and the Core Executive, Public Policy and Administration, Vol 25,No 1 Jan 2010.p26.

${ }^{35}$ 1.O'Broin, Dublin Castle and the 1916 Rising, London :Sidgwick and Jackson ,1966p17.

${ }^{36}$ Quoted in M. Herman, Intelligence Power In Peace and War ,Cambridge: Cambridge University Press, 1996, p10.

${ }^{37}$ Sun Tzu, The Art of War, translated by S.B. Griffith, Oxford :Oxford University Press,1963,p 144145 .

${ }^{38}$ M. Herman, Intelligence Power In Peace and War, Cambridge: Cambridge University Press,1996,p16.
} 
response was to create permanent military and naval staffs who would be charged with planning, mobilisation, and control of their forces. There was a continual need for information about the enemy and a good understanding of the capabilities of their own forces. The study of the former and process of identifying new enemies brought about the inception of permanent 'intelligence staffs'. In Britain this led the following institutional developments: "A new War Office Intelligence Branch was formed in 1873 and an Indian Intelligence Branch in 1878. The Admiralty created its Foreign Intelligence Committee in 1882; and the first War Office and Admiralty Directors of Intelligence (DMI and DNI) were both appointed in $1887^{\prime 39}$.

It was one of the incumbents of the latter post, Captain William Reginald Hall RN, who was to play such a pivotal role in the provision of intelligence to policy makers prior to the rebellion. Hall's post as DNI gave him access to the Royal Navy's pioneering signals intelligence unit, Room 40 .

Europe was the source of a type of policing the British state applied to Ireland in the latter half of the nineteenth century. This policing appeared on the European continent in the first half of the nineteenth century. Initially it was a response to the perceived threat of another French revolution: "The earliest separate institution for this purpose was the Russian Third Section of the Imperial Chancery founded in 1826,and later succeeded by the Okhrana and its eventual communist descendant ,the KGB". ${ }^{41}$ The skills this new kind of policing called for placed an emphasis on: the recruitment of agents, surveillance, and the ability in intercept communications between members of subversive organisations.

Great Britain did not have a political policing section , the 'Fenian Office', until $1881^{42}$.This was in response to a bombing campaign by Irish political extremists. The murder in Dublin of two key members of the Irish Executive one year later ${ }^{43}$ led to calls for similar efforts to be made in Ireland. This led to the setting up of a new independent Irish

\footnotetext{
${ }^{39}$ Ibid p16-17.

${ }^{40}$ See C. Andrew, Secret Service, The Making of the British Intelligence Community, London ;Sceptre Books, 1986 p139-194.

P. Beesley, Room 40: British Naval Intelligence 1914-1918, London: Hamish Hamilton, 1982.

${ }^{41}$ M. Herman, Intelligence Power in Peace and War ,Cambridge :Cambridge University Press 1996 p16.

${ }^{42}$ For a detailed account see B. Porter, Plots and Paranoia ,London: Unwin Hyman,1989 p103

43 They were Lord Frederick Cavendish, Chief Secretary for Ireland , and Thomas Burke permanent under secretary both of whom were murdered in May 1882 as they walked through Phoenix Park in Dublin.
} 
secret service department in Dublin Castle ${ }^{44}$. In England a second wave of bomb outrages led to the setting up of the 'Irish Branch' which replaced the 'Fenian Office' in March 1883.

The two police forces in Ireland tasked to obtain, organise, and evaluate political intelligence were the Royal Irish Constabulary ${ }^{45}$, and the Dublin Metropolitan Police ${ }^{46}$. Both these forces were involved in all three of these functions in the period leading up to the rebellion. It is important to understand how these forces were structured to perform these functions.

The RIC had an intelligence gathering structure which extended throughout Ireland. It was known as the 'Crimes Special' Branch. It was responsible to the Irish Executive for political intelligence, and for the collection of information about political and agrarian crimes. A succinct description of how this structure was configured can be found in an Army document written in 1922 :

"At Headquarters in Dublin an officer graded as a county inspector was in charge. His staff consisted of a district inspector and several clerks. There was a 'Crimes Special' sergeant at each County Headquarters, and, at most District Headquarters a specially selected constable. Two special men were also stationed at Glasgow, Liverpool and Holyhead. The duty of the 'Crimes Special' men was to prepare returns of the various political organisations in their areas ,to obtain an accurate knowledge of local political suspects and leaders, and to attend meetings and report speeches. Some of this information they obtained themselves, but they were also dependent on the uniformed members of the force most of whom had excellent local knowledge. All information was passed to the County Inspector for transmission to headquarters. ${ }^{47,}$

Political intelligence could be provided from all 32 counties of Ireland, with the exception of the City of Dublin, to the Irish Executive. This system was not without its weaknesses. The prime one being that initiative was often left to County Inspectors : "There was little guidance from above owing to the fact that the establishment of headquarters was

\footnotetext{
${ }^{44}$ B. Porter, Plots and Paranoia, London; Unwin Hyman ,1989 p103.

${ }^{45}$ The Royal Irish Constabulary was formed in 1836 as a result of the Irish (Constabulary (Ireland )Act ,1836. It was disbanded on the30th August 1922. The power to appoint and discharge members of the force, to make rules and to fix salaries was vested in the Lord Lieutenant of Ireland.

${ }^{46}$ The Dublin Metropolitan Police was set up in 1836 as a result of the Irish (Constabulary (Ireland )Act,1836..it was absorbed into the Garda Siochana in 1925.The DMP was closely modelled on London's Metropolitan Police They were both commanded by a Commissioner, who was not a police officer ,but a magistrate holding a Commission of the Peace. It was also an unarmed force.

${ }^{47}$ Record of the Rebellion In Ireland, Volume 11,Intelligence 1922,p4. IWM 72/2/2.
} 
so small that it was impossible to communicate fully with every County Inspector. The result was that at headquarters information on general subjects was meagre and patchy while information concerning individuals was limited to that about comparatively few persons of the most extreme type. ${ }^{48,}$

The Dublin Metropolitan Police had a different structure. Embedded in its organisation was a detective branch that was known as ' $G$ ' Division. This Division had a dual function. It was responsible for keeping the Irish Executive informed regarding political extremists in the City of Dublin. Yet its principal duty was the detection of crime in Dublin. This system was judged by the same army document to be effective: "Up to November, 1919, it was in charge of a Police Superintendent who was directly under the Chief Commissioner. This officer through his long service in Ireland, had a good knowledge of the various secret political organisations in the country, and his registry was sufficiently well-organised to enable him to personally compile a reasonably satisfactory report on such organisations or on any wellknown extremist, when he was called to do so."49 O'Halpin makes the point that although the two police forces worked closely together there was a difference in the intelligence material that they tended to produce: "The DMP detectives(of whom less than a dozen were concerned with political matters) concentrated on shadowing suspects ,attending political meetings and keeping premises under observation, whereas the RIC, a force developed specifically in response to political and agrarian crime were, better able to find out what was going on in each area and to detect changes in the political climate."

The beginning of the First World War these organisations were supplemented in a number important ways. An RIC officer, Inspector Ivan Price was appointed as an intelligence officer to the army's Irish Command with the rank of Major. He received all the intelligence produced by the two police forces and dealt with Colonel Kell head of MI5, based at the War Office in London. He also had access to other information. ${ }^{51}$

The Royal Navy set up a separate intelligence organisation in Ireland. It was headed by a W. V. Harrel, a former Assistant Commissioner of the

\footnotetext{
${ }^{48}$ Ibid $\mathrm{p} 4$.

${ }^{49}$ Ibid p5

${ }^{50}$ E.O'Halpin, British Intelligence in Ireland ,1914-1921 from C. Andrew and D. Dilks(eds), The

Missing Dimension ,Chicago: University of Illinois Press 1984 P55.

${ }^{51}$ Ibid p55.
} 
DMP. ${ }^{52} \mathrm{O}$ 'Halpin maintains that its remit was limited: 'Its activities were limited to 'Admiralty matters' and touched on more general questions only in relation to the loyalty of dockyard employees" ${ }^{53}$ Critically he maintains that this organisation had :"virtually no contact with naval intelligence in London". "This assertion is not borne out by the evidence from the Oliver memoirs :"He (Hall ) did a good job in Ireland, an officer in the RIC (it was the DMP) had been retired, a political scapegoat because he ordered constabulary to fire on a savage mob in Dublin. Hall made this officer his head agent in Ireland and he did splendid work". ${ }^{55}$ Crucially the Naval Intelligence Division of the Admiralty was not limited to the organisation and evaluation of intelligence that came from outside Ireland.

\section{INTELLIGENCE WARNINGS AND RESPONSES}

Having established the nature intelligence institutions upon which the British state was dependent upon both in Dublin and London it is intended to do outline briefly the nature and structure of the organisations that British intelligence attempted to penetrate. Then an assessment will be made as to how the intelligence that was obtained was affected by the power relations that existed within the institutions of the British state.

In terms of the nature and structure of these organisations the best analogy is that of a Russian doll. Hidden from view was a secret and subversive organisation called the Irish Republican Brotherhood ${ }^{56}$.Linked to the IRB was a sister organisation in the United States called Clan Na Gael ${ }^{57}$. This latter organisation had a partial public profile. The former organisation was to play a pivotal role in the rebellion :'The Easter Rising of 1916 was planned and executed by a secret revolutionary organisation, the Irish Republican Brotherhood (IRB) and, in particular, a small Military Council of Leaders ,Tom Clarke, Sean MacDermott, Patrick Pearse, Eamonn Ceannt, Joseph Plunkett and Thomas Mac

\footnotetext{
${ }^{52} \mathrm{He}$ had been dismissed from the DMP following the Bachelor's Walk shootings in 1914.

${ }^{53}$ E. O' Halpin, British Intelligence in Ireland,1914 -1921,from C. Andrew and D. Dilks (eds),The Missing Dimension, Chicago: University of Illinois Press,1984 p55-56.

${ }^{54}$ Ibidp p56

${ }^{55}$ Recollections, Vol 1 \&2 unpublished memoirs of Admiral of the Fleet Sir Henry Oliver,OLV12 National Maritime Museum p164.

${ }^{56}$ The IRB was a secret revolutionary organisation that was founded in March 1858.Its members believed in the illegal use of force to establish an independent Irish Republic. This organisation set up a Military Council in May 1915.

${ }^{57}$ In response to the establishment of the IRB in Dublin a sister organisation was founded in New York ,the Fenian Brotherhood by John O'Mahony in 1858.Its stated objectives were to establish by the force of arms an Independent Ireland. It was also designed to assist the IRB based in Ireland in achieving this aim. It changed its name to Clan na Gael (family of the Gaels) in the late $19^{\text {th }}$ century.
} 
Donagh. ${ }^{, 58}$ Linked to the IRB and Clan Na Gael were two organisations with a public profile: the Irish Volunteers and the Irish Citizen Army. ${ }^{59}$

The British state obtained intelligence about the links between the IRB and Clan na Gael and the Irish Volunteers from the Detective Department of the DMP as early as December 1914.They had been successful in placing an agent inside the Irish Volunteers: "I beg to report that, according to an informant ,the Clan- na-Gaels have taken over military control of the Sinn Fein Section of the Irish Volunteers...All matters of policy will be determined by the Clan na Gael Executive. The funds will remain for the present, subject to audit, in the hands of the Irish Treasurers. The informant adds that an agent from America will likely visit this country on an early date to carry out the terms of the Alliance The Irish Republican Brotherhood will also have representation on this new Executive, which will receive financial support from the Irish Societies in America". ${ }^{60}$

This intelligence was incorporated into a Cabinet document that was dated January 1915.The assumption can be made that members of Cabinet were in receipt of this information. Secondly the veracity of this intelligence was endorsed by Brien's line manager who added that :"This information comes from a good source and is believed to be correct." The use of an agent yielded further detailed information, about identities of the recipients of these funds :'Before the split between the National and Irish Volunteers considerable funds were coming from America and being paid into various banks in Dublin to the account of Mr John MacNeill, President of the General Council and Executive Committee, and Mr M.J. O'Rahilly, Treasurer, or to the joint account of these two gentleman. ${ }^{, 62}$ The money was being used for two things: the purchase of arms, and the funding of seditious newspapers and leaflets ${ }^{63}$.One of these

\footnotetext{
${ }^{58}$ M. Foy \&B. Barton, The Easter Rising, Stroud: Sutton Publishing 1999,p1.

${ }^{59}$ The Irish National Volunteers came into existence in November 1913.It was in many respects a response to the founding of the Ulster Volunteer Force raised to resist the introduction of Home Rule into Ireland By June $1914,65,000$ men had enrolled. The control of this organisation was vested in Mr John Redmond, leader of the Irish Nationalist party. By October 1914 there had been a split and the Irish Volunteers under the nominal control of John MacNeill. This new organisation was pledged to' secure the abolition of the system of governing Ireland through Dublin Castle and the British military power, and the establishment of a National Government in its place'. Their estimated total strength was about 15,200 at the time of the rebellion. The Irish Citizen Army had been founded in 1913.It was based solely in Dublin, and membership was almost exclusively confined to a proletarian base. Its leader James Connelly joined the Military Committee of the IRB in January 1916.

${ }^{60}$ Memorandum from Chief Superintendent Owen Brien, $28^{\text {th }}$ December 1914 , Nathan Papers , Ms 478 Bodleian Library, Oxford.

${ }^{61}$ Ibid.

${ }^{62}$ The Royal Commission on the Rebellion in Ireland. Minutes of evidence and appendix of documents CD 8311, 1916 ,London: HMSO p4

${ }^{63}$ Ibid p4.
} 
documents can be described as crude geopolitical propaganda. It had outlined the strategic benefits that would accrue to an independent Ireland in the event of a German victory in the war $^{64}$. O'Halpin claims that it was not until 1915 that the police in Ireland had any reliable agents inside the Irish Volunteers: ${ }^{65, ' I n} 1915$ two low level informants, 'Chalk' and 'Granite' were place or found in the Irish Volunteers. These provided scraps of worthwhile intelligence, but they were not in a position to say what their leaders intended." 66

The second source of intelligence that the British state had access to were the telegraphic cables that were sent between the Imperial German Government in Berlin, and its embassy in Washington. These communications illuminated the relationship between the German government and Clan $\mathrm{Na}$ Gael and the IRB. This relationship had been forged on the $24^{\text {th }}$ August 1914 when the leading members of Clan Na Gael met the German Ambassador in New York:” The Irish representatives quite clearly stated their purpose, namely to use the opportunity of the European War to overthrow British Rule in Ireland." ${ }^{, 67}$ The German Government established a clandestine office of the German embassy in New York to facilitate this newly established relationship ${ }^{68}$. A key conduit was Sir Roger Casement ${ }^{69}$. He had first come to the attention of the British authorities by the publication in 1913 of a seditious pamphlet published under the pen name of 'Shan Van Vocht'. He outlined a pro-German geopolitical scenario: "An Ireland already severed by a sea held by German warships , and temporarily occupied by a German army, might well be permanently and irrevocably severed from Great Britain, and with common assent elected into a neutralised ,independent European state under international guarantees."70 In October 1914 Casement, funded by Clan Na Gael with $\$ 3000$, left

\footnotetext{
${ }^{64}$ Kuno Meyer's, 'Ireland ,Germany and the Freedom of the Seas', was published in America and circulated widely in Ireland. He had been Professor of Celtic Languages at Liverpool University. ${ }^{65}$ E.O'Halpin,The Secrtet Service Vote and Ireland, Irish Historical Studies,Vol 23.No 921983 p351. ${ }^{66} \mathrm{E}$. O'Halpin, The Decline of the Union, Dublin: Gill \& Macmillan 1987,p109.

${ }^{67}$ R.E .Doerries, Prelude to the Easter Rising, London :Frank Cass, 2000 p 3.

68 'Von Igel had established in the Autumn of 1914 what was ostensibly an 'advertising agency' in Wall Street .The business carried on there had nothing what ever to do with advertising. He was an official of the German Embassy and his office was practically a sub-bureau of the German Foreign Office at Washington .Von Igel was specially concerned with the German Irish intrigues. 'Documents Relative to the Sinn Fein Movement CMD 1108 ,London: HMSO 1921 p13.

${ }^{69}$ Sir Roger Casement was a former member of the British Diplomatic Service. He came from a Ulster protestant middle class background in Co Antrim. In September 1914 he wrote an open letter to the Irish people from New York In it he urged all Irishmen to avoid taking up arms against Germany. He also declared himself to be a founding member of the Irish Volunteers. This resulted in his pension from the Foreign Office being suspended , and MI5 opening a file on him. Arrested by the RIC near Tralee when he landed from a German U boat. He was tried and found guilty of treason. He was subsequently hung in 1916.

${ }^{70}$ Shan Van Vocht, Ireland ,Germany and the Next War, Belfast: Davidson \& Mc Cormack,1913,p6.
} 
New York for Berlin using a false passport using the assumed name of James E. Landy. ${ }^{71}$ When he arrived in Berlin, there were number of objectives he had been set. The first was a German Government declaration in favour of Irish independence. This was duly made by the German Government on the $20^{\text {th }}$ November 1914. However, there were other targets which he had been set: "Such as support for rebellion in Ireland ; a propaganda campaign in Germany in order to win public support for eventual German actions in Ireland; the formation of a military unit from Irish prisoners of war held by the Germans., ${ }^{, 72}$ Casement was actively involved in the last activity. Personally visiting the German POW camps at Zossen and Limberg in an effort to recruit an 'Irish Brigade' for the German government. ${ }^{73}$

The Admiralty did not remain passive with respect to Casement's activities. In December 1914, to the Director of Naval Intelligence, Captain William Reginald Hall $\mathrm{RN}^{74}$ went to extraordinary lengths to spring a trap. It received intelligence, probably through Room 40, that indicated that a Danish ship was being commissioned by the German Government to take Casement back to Ireland. As a response to this Hall chartered a yacht called the Sayonara. By the 15th December the yacht was cruising off the west coast of Ireland, and was under the command of Lt Symon RN, who along a selected crew of naval ratings affected American accents and pro Irish republican sympathies. The 'owner' of the yacht was a German-American called Colonel MacBride of Los Angles. He was in fact an SIS officer called Major W.R. Howells. ${ }^{75}$

In early January 1915 Hall sent the following message sent to Symon: "It is anticipated that $\mathrm{C}$ will arrive in the Danish steamer Mjolnir of Copenhagen -500tons. She is due to leave Christiansand on $9^{\text {th }}$ (January) and should be off the west coast of Ireland between the $13^{\text {th }}$ and the $15^{\text {th, }}{ }^{76}$ As well attempting to capture Casement, Hall used the suspicion that the Sayonara had generated with respect to the naval command in Queenstown and Royal Navy patrols off the Irish coast to gather intelligence about Irish republicans: "Those on board the Sayonara were so 'chivvied' by the British authorities that the 'bad boys' came to

\footnotetext{
${ }^{71}$ He was also accompanied by Eivind Adler Christensen, a Norwegian sailor he had met in New York.

${ }^{72}$ R.E. Doerries, Prelude to the Easter Rising ,London :Frank Cass ,2000 p7.

${ }^{73}$ Casement, despite the use of Catholic priests, only managed to get 57 British POWs to sign up for this Irish Brigade.

${ }^{74}$ Captain William Hall RN was appointed Director of Naval lntelligence in November 1914. Prior to that he had been Captain of the battle cruiser HMS Queen Mary. He held the position of DNI until 1919.

${ }^{75}$ For further details of this trip see the unpublished memoirs of Admiral Hall ,Chapter 2.Hall Papers

$3 / 3$ Churchill Archives Centre, Churchill College Cambridge

${ }^{76}$ Ibid p21.
} 
them like flies to a treacle - pot and they were able to meet almost everyone who was working against us." ${ }^{, 77}$ Hall also claimed that the efforts of Simon and Howell provided a force multiplier for British intelligence in Ireland in the period that preceded the rebellion: "It was largely due to their efforts that right up to the Irish rebellion of 1916 we were able to keep watch on the most disloyal elements with comparatively few men." 78 This is further evidence to show that Hall's organisation was running agents in Ireland. With respect to Casement, on this occasion, Hall's dependence on signals intelligence proved to be unreliable. By the $19^{\text {th }}$ January 1915, Hall was forced to admit defeat. On that date he sent Symon the following message :"We have lost track of C". ${ }^{79}$ The Sayarona returned to Portsmouth shortly after having received this message.

The other challenge that British intelligence faced was understanding how Germany's policy with respect to providing assistance to the IRB and the Irish volunteers was evolving. Initially the German High Command was presented with military plans from the IRB and the Irish Volunteers that entailed a German led invasion :"The original plan for the 1916 Rising involved an elaborate county-by-county rebellion, which would have depended for its success on a German backed invasion with the landing being at Limerick. This was the basis of the proposal put by Joseph Plunkett ${ }^{80}$ and Sir Roger casement to the Germans in 1915., ${ }^{, 81}$ By March 1916 the scope of the plan had narrowed to a request from Irish Revolutionary Headquarters ${ }^{82}$ for the following munitions: field guns, German gun crews and officers, machine guns, rifles and ammunition. The German High Seas Fleet should make a demonstration in the North Sea and a submarine should be detailed to Dublin Bay. ${ }^{83}$ Finally, the Germans decided to supply rifles and machine guns, and sortie elements of their High Seas Fleet to bombard a town in Kent. ${ }^{84}$ The weapons and ammunition were to be loaded onto a captured British ship from the Wilson Line that was renamed the Aud.

In terms of obtaining and evaluating intelligence, concerning German involvement in the rebellion, and the links to Clan na Gael, the IRB and the Irish Volunteers British intelligence was able to exploit a key

\footnotetext{
${ }^{77}$ Ibid p20

${ }^{78}$ Ibidp20

${ }^{79}$ Ibidp22.

${ }^{80}$ Plunkett joined the IRB in 1914 . He was also a member of the military committee. He travelled to Germany to meet Casement in 1915. He was tried by a Field General Courts Martial , found guilty and executed on the $4^{\text {th }}$ May 1916

${ }^{81}$ P.Bew ,Ireland ,Oxford :Oxford University Press ,2007 p374.

${ }^{82}$ This was the phrase used by Robert Monteith.

${ }^{83}$ Taken from R. Monteith, Casement's Last Stand ,Dublin :Michael F.Moynihan 1953.p134.

${ }^{84} \mathrm{See} \mathrm{p}$ for full details of this operation.
} 
weakness. There was no means of direct communication between the German General Staff and Admiralty and members of the IRB or Irish Volunteers in Ireland. Monteith who landed with Casement from U-19 makes this very clear :"We knew nothing of the progress of the organization in Ireland since my departure seven months earlier." ${ }^{, 85}$ An indirect route, using diplomatic telegrams, went from Berlin to the German Embassy in Washington DC and in the other direction. The Clan $\mathrm{Na}$ Gael organisation then used a secret courier to get messages to and from Ireland. ${ }^{86}$ The British were able to gain a detailed insight to the developing plans by intercepting this communications route to the United States, and back from the United States to Germany. These decrypts provided a means whereby Britain could monitor the assistance the German government was giving to the IRB and the Irish Volunteers. ${ }^{87}$

It has been claimed by Christopher Andrew that all three of the main German naval codes did not fall into British hands until December $1914^{88}$.Furthermore, it was not until the summer of 1915 that Hall set up a diplomatic annex to Room $40{ }^{89}$ However, diplomatic messages from the German Embassy in Washington to the Foreign office in Berlin were being read as early as September 1914:"'I am telegraphing, because written reports are too unsafe. I do not think it necessary in this matter to be too much exercised about American public opinion, as we are most likely to find friends here if we give freedom to oppressed peoples, such as the Poles, the Finns and the Irish.....The decisive point to me seems to me to lie in the question whether any prospect of an understanding with England is now in view, or must we prepare ourselves for a life and death struggle. If so, I recommend falling in with Irish wishes, provided that there are really Irishmen who are prepared to help us." 90

This intercepted message raises the question of which cable route the Germans were using after their own transatlantic cables were cut at the beginning of the war? The Command Paper of 1921 stated its intention of not :"disclosing sources of information and channels of communication". ${ }^{91}$ One of the routes used was referred to in the Admiralty

\footnotetext{
${ }^{85}$ Ibid p146.

${ }^{86}$ P. McMahon, British Spies and Irish Rebels, Woodbridge Suffolk: The Boydell Press.2008.p20.

${ }^{87}$ These decrypts demonstrated an active link between the IRB, Clan Na Gael and the German Government. They were published in an initial tranche by the British Government in May 1918 and by a government Command Paper in 1921.

${ }^{88}$ C. Andrew, Secret Service The Making of the British Intelligence Community ,London: Sceptre Books, 1986 p142-145.

${ }^{89}$ Ibid p 167

${ }^{90}$ Documents Relative to the Sinn Fein Movement, London: HMSO,1921 p3.

${ }^{91}$ Ibid p3.
} 
as the "Swedish roundabout" allowed the Germans to use their trans- Atlantic cables. In a memorandum written for Lloyd George in 1920 by a former AttorneyGeneral for Ireland, he reveals the two routes the British signals intelligence was intercepting :"Care has been taken not to show the channel of communication of telegrams passing through the Swedish Ministry at Stockholm or Buenos Aires ,or those passing through Madrid.",93

The real breakthrough came on the 10th February 1916.This was the date when the British intercepted and decrypted the following message 'on the position in Ireland ' from John Devoy. ${ }^{94}$ It had been delivered to the German Embassy in Washington for transmission to Berlin: "Unanimous opinion that action cannot be postponed much longer. Delay disadvantageous to us. We can now put up an effective fight. Our enemies cannot allow us much more time .The arrest of our leaders would hamper us severely. Initiative on our part is necessary .The Irish regiments which are in sympathy with us are being gradually being replaced by English regiments. We have therefore decided to begin action on Easter Saturday. Unless entirely new circumstances arise we must have your arms and munitions in Limerick between Good Friday and Easter Saturday. We expect German help immediately after beginning action. We might be compelled to begin earlier." 95

A further message was intercepted on the $18^{\text {th }}$ February that confirmed the earlier proposals of the IRB. This message was sent using another route which the British were monitoring. The American transatlantic cable which Bernstorff, the German Ambassador, was given access to as means of facilitating President Wilson's peace initiative ${ }^{96}:$ 'The Irish leader, John Devoy, informs me that rising is to begin in Ireland on Easter Saturday .Please send arms to (arrive at) Limerick, west coast of Ireland between Good Friday and Easter Saturday. To put it off longer is impossible. Let me know if help may be

\footnotetext{
${ }^{92}$ C. Andrew, Secret Service The making of the British Intelligence Community, London: Sceptre Books, 1986 p168.

${ }^{93}$ TNA PRO, Prem 1/7 December 1920.

${ }^{94}$ Devoy was described in the following way in the 1921 document.: "He was during the war the chief agent in America for communication between Germany and Sinn Fein ,and was described by Von Skal ,one of Count Von Bernstorff's staff in Washington, as their "Confidential Agent "in a despatch from the German Embassy in America to Berlin in February 1916.

${ }^{95}$ Documents Relative to the Sinn Fein Movement ,London :HMSO ,1921 p9.

96 " 'Comment' attached surreptitiously by Count Bernstoroff to a message regarding the "Lusitania" negotiations, which was sanctioned and passed through by State Department of American Government", See Documents Relative to the Sinn Fein Movement ,London :HMSO,1921 p13.
} 
expected from Germany. Bernstorff." 97 Another message was intercepted from the Foreign Office in Berlin to the German Embassy in Washington on the $4^{\text {th }}$ March 1916:"Between $20^{\text {th }}$ and the $23^{\text {rd }}$ April, in the evening, 2or 3 steam trawlers could land 20,000 rifles and 10 machine-guns, with ammunition and explosives at Fenit Pier in Tralee. Bay .Irish pilot-boat to await the trawlers at dusk, north of the island of Inishtooskert at the entrance of Tralee Bay, and show two green lights close to each other at short intervals. Please wire whether the necessary arrangements in Ireland can be made secretly through Devoy. Success can only be assured by the most vigorous efforts" ${ }^{\prime 98}$. The arrangement with respect to the pilot boat had been requested by Captain Von Haugwitz of the German General Staff. ${ }^{99}$ Monteith also confirms that the original plan to send two trawlers was later cancelled and a single ship substituted. ${ }^{100}$

The only information that British intelligence did not have access to was the extent to which the IRB and the Irish Volunteers would be able to respond to the arrangements that had been proposed by the Germans. On the $12^{\text {th }}$ March two messages were intercepted by the British that completed the picture : "On 12 ${ }^{\text {th }}$ March,1916,a code message in German was sent by wireless from the German Embassy in Washington to Banker Max Moebius ,Oberwallstrasse ,Berlin: translated it was: "National Germania Insurance Contract certainly promised .Executor is evidently satisfied with proposition.. Necessary steps have been taken -Henry Newman.

Decoded it reads :

Irish agree to proposition.

Necessary steps have been taken. ${ }^{101}$

The second message was sent from the German Embassy in Washington to the Foreign Office in Berlin, and revealed that the Clan $\mathrm{Na}$ Gael were using, as previously stated, a courier for their communications with Ireland ${ }^{102}$ : "Irish agree. Will follow instructions. Details sent to Ireland by messenger." 103

By mid March 1916, the British authorities had a comprehensive understanding and knowledge of the planned rebellion :'The decrypts revealed the extent of the German complicity in the Easter Rising

\footnotetext{
${ }^{97}$ Idibp13.

${ }^{98}$ Ibid p13.

${ }^{99}$ R. Monteith, Casement's Last Adventure, Dublin: Michael F. Moynihan,1953,p134.

${ }^{100}$ Ibid p135.

${ }^{101}$ See Documents Relative to the Sinn Fein Movemernt ,London:HMSO,1921 Ibid p13.

${ }^{102}$ See $\mathrm{p} 15$.

${ }^{103}$ Ibidp11
} 
....between 1914 and 1917 Room 40 intercepted over 30 messages between Bernstorff and Berlin indicating German support for the extremists" $" 104$.

Given the intelligence that Britain now had obtained on this planned rebellion, it is important to pose two questions. First was this information communicated to the authorities in Ireland? Secondly, how comprehensive was the dissemination of intelligence to both the mobile and stable forces of law and order ${ }^{105}$ ? O'Halpin has claimed that Dublin Castle was not informed that the Aud had left for Ireland loaded with arms until the $17^{\text {th }}$ April. Furthermore, the army commander in Ireland General Friend was informed of this by Brigadier General Stafford. He in turn had learned this 'not officially but casually" ${ }^{106}$ from Admiral Bayly, Admiral commanding the Western Approaches at Queenstown.

Yet there is evidence to suggest that there was a co-ordinated response by both the military(stable force ) and the two police forces in Ireland(mobile force) to this intelligence. The Commanding Officer of the Queenstown Garrison ,Brigadier General Stafford, has given an insightful account: "On Sunday the 16th (April) inst I received information that two German submarines either alone or escorting a ship disguised as a tramp steamer left Germany on the $12^{\text {th }}$ inst with a view to landing arms and ammunition on the SW Coast of Ireland. It was further stated that the arms etc were to be conveyed to Limerick and that a rising was timed for Easter Eve(today )I immediately wrote to the GOC in C giving him my information. On the $17^{\text {th }}$ I proceeded early with Colonel Buckley G.S.O. to Limerick, interviewed the DIRIC in the absence of the County Inspector, gave him such of my information as I thought desirable and asked him to communicate this at once secretly to CI Clare and CI Kerry. I also saw the $\mathrm{OC} 4^{\text {th }}$ Leinster Regt ,gave him all the necessary information and directed him to afford assistance if called upon, by the RIC to picket roads leading into Limerick City."107

The warning also went to the top of the British administration in Ireland. Stafford's intelligence, was not just passed to the army's Irish Command Headquarters in Dublin. The head of the RIC, and the Under-

\footnotetext{
${ }^{104}$ Taken from Patrick Beesly's book Special Intelligence quoted in, D.Ramsay 'Blinker 'Hall :Spymaster ,Stroud: Spellmount.2008 p133.

${ }_{105}$ This was the phrase that was coined by J.F.C.Fuller,See $\mathrm{p} 5$

${ }^{106}$ O,Haplin makes this claim based on evidence give to the Royal Commission on the rebellion See E,O’Halpin, British Intelligence in Ireland ,1914-1921,from C.Andrew\& D.Dilks, The Missing Dimension Chicago:University of Illinois Press 1984p59.

${ }^{107}$ Letter from Brigadier General Stafford, Headquarters, Queenstown Garrison,22 ${ }^{\text {nd }}$ April 1916.Nathan Papers MS 476,Bodleian Library ,Oxford.
} 
Secretary, Sir Matthew Nathan, the most senior civil servant in Ireland were also in receipt of this information: "On the 17th of that month (April) the Major-General Commanding (GOC Ireland ) showed to the Under Secretary (Sir Matthew Nathan) at the Castle a letter from the Officer Commanding Queenstown defences which told of a contemplated landing from a German ship, rigged up as a neutral and accompanied by two submarines., of arms and ammunition on the south-west coast with a view to their reaching Limerick, and of a rising timed for Easter eve..... The letter was shown to the Inspector-General, Royal Irish Constabulary, and the County Inspectors in the south and south-west counties were put on their guard. The Chief Commissioner, Dublin Metropolitan Police, was also informed so that a watch could be kept on the turbulent spirits in Dublin , and he arranged with the military authority for armed pickets of 100 men to be henceforth nightly available at each of the four main barracks. There were the usual meetings of suspects in Dublin on the $17^{\text {th }}$ and the $18^{\text {th. }}$. “108

The Prime Minister, Herbert Asquith had been in receipt of an intelligence warning that predated Stafford's information by 24 days : "On the $23^{\text {rd }}$ March ,1916, the Director of Military Intelligence informed General Headquarters, Home Forces, that he had received information from an absolutely reliable source that a rising in Ireland was contemplated at an early date, and that extremists in that country were in communication with Germany with a view to obtaining German assistance. He added that the rising was timed to take place on $22^{\text {nd }}$ April and that Irish extremists has asked Germany to supply arms and ammunition in Limerick by that date. Acting on similar information the Admiral Queenstown, issued a stringent order for the patrolling of the Irish Coast. ${ }^{109}$ "O'Halpin maintains that this intelligence obtained in the third week of March was not passed onto the Irish authorities. ${ }^{110}$

. On the $12^{\text {th }}$ April 1916 Sir Roger, Robert Monteith ${ }^{111}$ and Daniel Julian Bailey ${ }^{112}$, both members of the "Irish Brigade" ${ }^{113}$ embarked on U-

\footnotetext{
${ }^{108}$ The Royal Commission on the Rebellion in Ireland .Minutes of evidence and appendix of documents, London: HMSO 1916 p7.

${ }^{109}$ Memorandum from the Asquith Papers, Box 42, Folder 5-9, Bodleian Library ,Oxford.

${ }^{110}$ E.O'Halpin ,The Decline of the Union, Dublin:Gill and MacMillan,1987 p113.

${ }^{111}$ Robert Monteith was a former regular soldier in the British Army who had served in the Boer War.He was dismissed from the British Army and deported from Ireland under the Defence of the Realm Act in November 1914.He subsequently became a 'Captain' in the Irish Brigade. He was also a member of the IRB.

${ }^{112}$ Private Bailey had served in the Royal Irish Rifles in the early part of the war, but had been taken prisoner by the Germans. He had been recruited by Casement from a German POW camp to join the Irish Brigade.
} 
20 at Wilhelmshaven. The night before their departure they had been given a final briefing by the German General Staff. They were given two important things: a code for communication; and a clear commitment of further supplies of arms and ammunition if required: "The code, as the photograph shows, was devised in order that we might communicate with the Germans should operations be prolonged, necessitating further supplies of ammunition and material." $" 114$ This line of communication was to be maintained from the $22^{\text {nd }}$ April to $20^{\text {th }}$ May 1916. Due to a mechanical failure they transferred to U19 after a day and a half at sea. The Aud set sail on the $10^{\text {th }}$ April disguised as a Norwegian steamer commanded by a reserve Lieutenant Karl Spindler. The crew consisted of three officers one helmsman, and 15 sailors of the Imperial German Navy. It was carrying a cargo of 20,000 Italian rifles that had been captured by the Germans from the Russian Army on the Eastern Front, plus 10 million rounds of ammunition, 10 machine guns ,one million rounds of machine-gun ammunition, explosives, landmines, bombs, and hand grenades. ${ }^{115}$

At midnight on the $20^{\text {th }}$ April a German U-boat , U 19, commanded by Captain Weisbach, arrived at the pre-arranged rendezvous point. This was a one mile north west (NW 16') of Inishtooskert Island, at the entrance of Tralee Bay on the west coast of Ireland. Two important meetings had been scheduled to take place there. First the Aud was to rendezvous with $\mathrm{U}-19$ during the period $20^{\text {th }}$ to the $23^{\text {rd }}$ April after $10 \mathrm{pm}$. Secondly a pilot boat, which was to show two green lights, was to meet U19 and take Casement and his two companions ashore. The first meeting never took place. The Aud ,due to a navigational error, was several miles from this point. This was compounded by the fact that the Royal Navy was already shadowing the ship:" The Aud had been shadowed for a considerable distance down the coast and kept under close observation while in Tralee Bay." ${ }^{, 16}$ The increased patrolling ordered by the Admiral at Queenstown had the required effect. HMS Bluebell was one of the patrolling vessels : "The Commander of the Bluebell took definite action by approaching to within about 3 miles distance from the "Aud" and asking what is your name? Where do you

\footnotetext{
${ }^{113}$ The reason why they accompanied Casement was to man two machine guns concealed on the deck of the Aud in case of an attack was made on the ship while unloading. See R .Monteith, Casement's Last Adventure,Dublin:R.Moynihan,1953p138.

${ }^{114}$ Ibid p141

${ }^{115}$ What is curious about this huge arms shipment is that it has been described by one of the leading historians of the 1916 rebellion as:' a comparatively insignificant cargo of second-rate arms'. See C.Townshend, Easter 1916,The Irish Rebellion ,London :Penguin books 2006 p126.-127.

${ }^{116}$ Statement by Signalman Sidney Waghorn, H.M.S.Bluebell. This account is attached to and classified with that of Constable Reilly's. Constable B.Reilly ex RIC, Document No WS 349, Bureau of Military History 1913-1921,Military Archives, Dublin.
} 
come from? To which the Aud replied .'The Aud from Bergen to Genoa with cargo'; then to the question what are you doing here? the Aud replied I have lost my bearings, and I am taking them from the Irish coast ${ }^{117}$ "This ruse failed as the Aud was then shadowed and informed that she was being escorted 'to Queenstown for search'. At the position of one mile south of the lightship at Daunts Rock, at the entrance to Cork Harbour, Lieutenant Spindler took action to scuttle his ship: "Suddenly the Aud stopped ,hoisted two German naval ensigns, and lowered her boats, into which got the officers and seamen -about thirty in number ,in naval uniform. Then an explosion occurred in the Aud and she went to the bottom". ${ }^{118}$ Grob-Fitzgibbon maintains that the Royal Navy sank the Aud. ${ }^{119}$

The second meeting also failed to happen. The pilot boat never materialised. The initial plan had been for Casement, Monteith, and Bailey to go ashore in the pilot-boat, which would also make contact with the Aud. Captain Weisbach had an alternative set of orders to be used if the pilot boat failed to appear. This was to land the three men in the submarine's inflatable dinghy. This plan was not without its risks. Due the war the local population had been urged by the RIC to report any activity that could be the prelude to an invasion. There was a witness to the three men moving inland from the beach: "The instructions we got were to request the people living along the coast to inform us if they saw any indication of a hostile landing .They always reported anything unusual they saw and this instruction was in existence from the outbreak of the war. It was when Mary (Gorman ) was milking cows between 3 and 4 o'clock in the morning that she observed three men coming from the direction of the sea" ${ }^{120}$. Secondly there was a report made by a member of the public at 8am to Ardfert RIC station. It concerned a boat floating at the edge of the shore. This resulted in patrols being sent out in the local area. It was one of these patrols that encountered Casement hiding in McKenna's Fort. Of the two other men landed from U 19, Monteith evaded capture and Bailey was arrested two days later. Casement's arrest came after an exchange with two RIC officers, Constable Reilly and Sergeant Hearne, in which he tried to sustain a legend with respect to his identity ${ }^{121}$. News of his capture reached Dublin

\footnotetext{
${ }^{117}$ Statement by Signalman Waghorn, H.M.S Bluebell.

${ }^{118}$ L. Bayley ,Pull Together ,London: Harrap,1939 ,p203.

${ }^{119}$ See B.Grob-Fitzgibbon, Turning Points of the Irish Revolution, London: Palgrave Macmillan,2007 p102.

${ }^{120}$ Constable B. Reilly ex RIC. Document No WS349,Bureau of Military History 1913-1921,Military Archives ,Dublin.

${ }^{121}$ The following exchange took place between Constable Reilly and Casement:" $\mathrm{He}$ (Casement ) said :"I am an Englishmen. "Where did you come from? I asked, and he answered, "My name is Richard Morton and I come from Denham in Buckinghamshire .I then asked him what was his business to
} 
Castle by the evening of the $21^{\text {st }}$ April and was passed on to the Prime Minister Asquith :"At 6.30 pm the RIC Office in Dublin Castle received the following message from District Inspector W.A. O'Connell in Tralee :"This morning patrol from Ardfert captured boat, one thousand rounds of ammunition ,three Mauser pistols ,maps ,papers, all German .Arrested one prisoner, two escaped, believed to have come off Dutch vessel. ${ }^{122}$ "The mobile and stable forces of law and order co-operated closely in the matter of Casement's security. At 10.30pm the DI O'Connell contacted the army garrison at Queenstown and informed them that he had made an important capture. As a consequence he feared an attempted rescue. By $11 \mathrm{pm}$ the army had ordered 100 men of the $3^{\text {rd }}$ battalion Royal Dublin Fusillers to proceed to Tralee to foil any attempted rescue of Casement ${ }^{123}$.

With the interception of the Aud and Casement's arrest, the plans that had been made to co-ordinate the landing of the weapons took on a farce like quality. On the 21st April Irish Volunteers Austin Stack and the Cornelius Collins were attempting to oversee a plan that went very wrong. That evening a car was driven off the end of Ballykissane Pier and all the occupants bar one were drowned. They were also arrested on charges of conspiracy to land arms. ${ }^{124}$.

The events that have been described represented a real coup for British intelligence. Furthermore, the Royal Navy, the British Army and the RIC had all co-operated in an effective manner. However, it would but wrong to attribute Casement's capture solely to the signals intelligence provided by Room 40:"We knew about Sir Roger Casement's traitorous expedition to Ireland in a German submarine partly from RM40 and partly from the Head agent". ${ }^{125}$ These events had an effect on the leadership of the Irish Volunteers. News of Casement's arrest and the interception of the Aud by the Royal Navy caused Eoin MacNeill, the Chief of Staff to issue a 'countermanding order' against mobilisation. This was distributed throughout the country by messenger and adverts in the national press. The original plan had a key mutually reenforcing element that now become unhinged: "The Easter Sunday manoeuvres would serve as a distraction from the arms landing in

\footnotetext{
which he replied .'I am an author and I am at present writing a book on the life of Saint Brendan and I expect I will be able to collect some statistics in the locality. "Constable B. Reilly ex RIC, Document NO WS349 ,Bureau of Military History 1913-1921,Military Archives ,Dublin.

${ }^{122}$ Asquith Papers ,Box 38,Fol 15 ,Bodleian Library ,Oxford University.

${ }^{123}$ Nathan Papers ,MS 476,Bodleian Library, Oxford University.

${ }^{124}$ See The Royal Commission on the Rebellion in Ireland .Minutes of Evidence and Appendix of Documents CD 8311 1916, p7.

${ }^{125}$ Recollections Vol $1 \& 2$, The unpublished memoirs of Admiral of the Fleet Sir Henry Oliver ,National Maritime Museum OLV12. p164.
} 
Munster, and this in turn would enable the Volunteers to deter or resist any attempts at suppression by the British authorities". ${ }^{126}$ The possibility of mobilising the Irish Volunteers throughout Ireland had now been abandoned. ${ }^{127}$ There has been an ongoing historical debate as to how damaging this order was to the rebellion when it finally broke out in Dublin. ${ }^{128}$

\section{POLICY ASSUMPTIONS AND INTELLIGENCE WARNINGS}

The successful response by the British authorities in acting to prevent the landing of German arms, and securing Casement's arrest, stands in sharp contrast to the reaction to intelligence that was being provided by the DMP and the RIC to key policy makers in Dublin Castle. Townshend has argued that the: "British authorities were bombarded with warnings about the approaching rebellion." ${ }^{129} \mathrm{He}$ argues that it was an intelligence failure not a failure of response. Furthermore, he makes no reference to the assumptions that motivated policy makers to within hours of the outbreak of the rebellion: "This was a classic instance of intelligence failure: caused not by a lack of information, but by the blinkered view of those whose job was to interpret it." ${ }^{, 130}$ Major Price at army headquarters is cited as a source of this failure of interpretation. ${ }^{131}$

The assumptions of the senior civil servant in Dublin Castle, Sir Matthew Nathan need to be understood: "Like Birrell he saw his overriding task as being to keep the situation as quiet as possible, to prepare the way for the constitutional nationalists to take over when

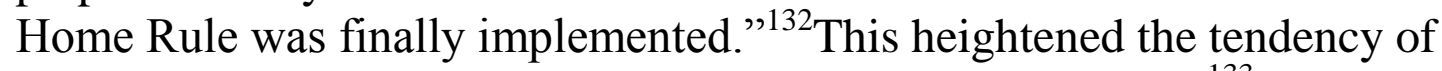
what Betts has described as the 'allure of deferring decision'. ${ }^{133}$ For example despite being shown a letter on the $17^{\text {th }}$ April that indicated, through signals intelligence intercepts, a direct connection between the German government and the IRB ${ }^{134}$ Nathan claimed in his evidence to the Royal Commission that it was only the interception of the 'Aud' and the capture of Casement three days before the rebellion, that proved the link between the IRB and the German Government. Prior to that reference is

\footnotetext{
${ }^{126}$ M. Laffan, The Resurrection of Ireland, Cambridge: Cambridge University Press,1999p39.

${ }^{127}$ For a longer account of this decision see F. McGarry, The Rising Ireland :Easter 1916,Oxford : Oxford University Press 2010 p117.

${ }^{128}$ See C. Townshend,Easter 1916 The Irish Rebellion,London :Penguin Books,206 p141-143.

${ }^{129}$ Ibib p143.

${ }^{130}$ Ibidp 143

${ }^{131}$ Ibid p143-144.

132 Ibid p87.

${ }^{133}$ R.K. Betts, Surprise despite warning, from C.Andrew and R.J.Aldrich Secret Inteligence A Reader,London: Routledge 2009 p97

${ }^{134}$ See p19.
} 
made only to German organisations in the United States: "Until three days before the insurrection there had been no definite proof of any connection between the anti-British party in Ireland and the foreign enemy. It was of course known that the Clan $\mathrm{Na}$ Gael, which was in touch with the Republican Brotherhood and the Volunteers were in alliance with German organisations in America". 135

This statement of Nathan's raises a key point. Did evidence of 'hostile association $^{136}$ as defined by the Defence of the Realm Act 1914 only become actionable on the $21^{\text {st }}$ April $1916^{137}$, and before that date it was not possible to treat these citizens as external enemies? In fact there existed a range of legislation that was on the statue books prior to the First World War that could have been applied, but was not ${ }^{138}$. These acts gave the Irish Executive extensive powers for dealing with riotous or unlawful assemblies. Yet their utility, and the intelligence warnings, were ignored.

To evaluate to the degree to which there was an intelligence failure or a failure of response which was a product of certain assumptions, it is important to assess the quality and extent of the intelligence the RIC and the DMP were supplying. In 1922 the British Army's view of the Irish Executive in terms of the receipt of intelligence was simply one of a lack of resources: "Information regarding rebel activities was very meagre, owing to the fact that during the Chief Secretaryship of Mr Birrell the Secret Service had ceased to exist , and Sinn Fein had every opportunity of planning and organising in security" ${ }^{139}$ This is not an accurate picture. What is being referred to is a portion of the secret service vote that was being spent by the Irish Executive on running agents. Since the beginning of the Liberal Administration in 1906 the amount had declined from $£ 2,634$ to $£ 932$ in 1916 . $^{140}$

Grob-Fitzgibbon has argued that the period from 1912 to 1914 saw the RIC and the DMP successfully gather accurate intelligence:

\footnotetext{
${ }^{135}$ The Royal Commission on the Rebellion in Ireland .Minutes of Evidence and Appendix of Documents CD 83111916 p6.

${ }^{136}$ Once this was established British citizens could be interned.

${ }^{137}$ The date of Casement's arrest.

${ }^{138}$ The following Acts are listed by the Royal Commission on the Rebellion as having pertinence to the period leading up to the rebellion: The Explosives Substances Act 1883, The Unlawful Drilling Act 1819, Criminal Law and Procedure(Ireland )Act 1887.It was also noted that the Whiteboy Acts were also still on the statue books. This was legislation that had been passed by the Irish Parliament before 1800 .

${ }^{139}$ Record of the Rebellion in Ireland in 1920 -1921,Vol. 1 Operations p4 IWM 72/82/8

${ }^{140}$ E.O’Halpin ,The Secret Service Vote and Ireland .1868-1922, Irish Historical Studies Vol 23,No 92 p323.
} 
"Throughout this period, the British security forces collected precise and thorough intelligence, yet politicians at the highest levels of government refused to act on this intelligence, thus allowing the illegal armies to grow." was, a Unionist organisation set up to parry the intention of the Liberal Government of setting up a devolved parliament in Dublin. They began to import arms, some from Germany, into Ireland from late 1913.The initial response of the government was to issue a Proclamation under the Customs Consolidation Act of 1876 banning the importation of weapons into Ireland. Instead of enforcing this act, political expediency triumphed :'It has been stated that as a matter of policy it was decided by the Government not to take proceedings against those who were responsible for this breach of the law"142. This policy manifested itself again when the Catholic Irish National Volunteers landed arms at Howth near Dublin in July 1914. In fact the Irish Government decided to withdraw the Proclamation the day after the First World War broke out on the $5^{\text {th }}$ August 1914.The other aspect that the government failed to deal with in a coherent manner was sedition.. This took the form of anti-recruiting meetings, pamphlets, and seditious papers which were widely circulated in Ireland during the First World War.

In terms of intelligence warnings that were being given by the 'Crimes Special' Branch of the RIC and 'G' Division of the DMP from mid 1914 onwards reports there were clear references to the consequences of the conditions that the government was permitting to develop. On the $15^{\text {th }}$ June 1914 the Inspector-General of the RIC submitted the following report.: "In Ireland the training and drilling to the use of arms of a great part of the male population is a new departure which is bound in the not distant future to alter all the existing conditions of life.....Events are moving. Each county will soon have a trained army far outnumbering the police, and those who control the volunteers will be in a position to dictate to what extent the law of the land may be carried into effect. ${ }^{143 \text { " On }} 7^{\text {th }}$ September 1914 the DMP submitted to the government a report that stated that: "There is no doubt that so far as Dublin is concerned the majority of the Irish National Volunteers would follow the lead of the extreme section, and hints have been given that they are not without hope of being able to assume and establish control of the Government of Ireland before the present difficulties are over and that

\footnotetext{
${ }^{141}$ B. Grob -Fitzgibbon, Turning Points of the Irish Revolution, London: Palgrave Macmillan, 2007 p10.

${ }_{142}^{142}$ Royal Commission on the Rebellion in Ireland, London: HMSO 1916 .p5.

${ }^{143}$ Ibid p8.
} 
they may attempt some escapade before long." 144 The Detective Department of the DMP carried out a successful surveillance at the first Annual Convention of the Irish Volunteers in 1914. In fact Nathan received notes of speeches made by Irish Volunteers at this meeting.: "Speeches of the most inflammatory and revolutionary character were delivered. The leaders predicted rebellion and the shedding of blood "in the great fight of Ireland against the British Empire". ${ }^{145}$ There were no specific warnings, at this stage, about the date of a rebellion. This analysis had to pass through the prism of being unable to predict what the key decision makers would do about these warnings.

They conflated with two important issues. First was the political relationship between the Chief Secretary Augustine Birrell, Sir Matthew Nathan, the senior civil servant in Dublin, and the leaders of the Irish Parliamentary Party: "His (Birrell's) nine year as Chief Secretary were characterised by his cultivation of the close links with the Nationalist leaders". ${ }^{146}$ The second was the impact of the First World War, and the requirements of recruiting that drove Asquith's government to pass on the $18^{\text {th }}$ September 1914 the Irish Home Rule Bill, and a second bill suspending its operation until after the war: "Lord Kitchener, the new Secretary of State for War, had told them (the Cabinet) that whilst recruits in Ulster were plentiful, outside of Ulster he had been forced to reply on English troops to fill the gaps in the Irish Regiments. As a result they needed Redmond's Irish Volunteers". ${ }^{147}$

This need to ensure a buoyant recruitment in the south of Ireland dovetailed with the policy that Birrell was following. He wanted to keep the political situation in Ireland as quiet as possible. This context would pave the way for the constitutional nationalists, led by John Redmond and John Dillon, to head up a devolved government in Dublin when the Home Rule Bill was finally implemented. Paradoxically Birrell was less than convinced about the efficacy of the policy he was following:" Even with the Home rule on the Statue Book the chance of its ever becoming a fact was so uncertain, the outstanding difficulty about Ulster so obvious , and the details of the measure so unattractive and difficult to transmute into telling platform phrases that Home Rule as an emotional flag fell out of daily use"

\footnotetext{
${ }^{144}$ Ibidp8

${ }^{145}$ Ibid $\mathrm{p} 8$

${ }^{146}$ E. O'Halpin, The Decline of the Union, Dublin: Gill and Macmillan, $1987 \mathrm{p} 81$.

${ }^{147}$ B. Grob-Fitzgibbon, Turning Points of the Irish Revolution, London: Palgrave Macmillan,2007 p69

${ }^{148}$ The Royal Commission in the Rebellion in Ireland .Minutes of evidence and appendix of documents Cd 8311 ,London HMSO Cd 8311 p21
} 
Nathan, who had only taken up his post prior to the outbreak of the First World War, has been described as a :" loyal and conscientious, workaholic Under Secretary" "He displayed two characteristics that were to affect his response to intelligence warnings. First he had a concept of loyalty that did not permit him to inform his political chief when he thought that he was wrong ${ }^{150}$. Secondly, he permitted the Deputy leader of the Irish Parliamentary Party, John Dillon to exercise undue influence on his decision making in the months preceding the rebellion. In 1915 there is clear evidence to suggest the impact that Dillon was having on Nathan :'We talked of the state of Ireland' recorded Nathan after another meeting in December', and the Sinn Fein movement which he now regards as very serious but still advised me to keep my hands off the organisers" ${ }^{\prime 151}$. The Chief Secretary, when cross- examined at the Royal Commission about the influence of Dillon laid emphasis on being unable to prove hostile association: "He (Dillon ) thought it(Sinn Fein)dangerous, but yet he was against it in absence of proof of hostile association with the enemy. If there had been evidence of hostile association with the enemy which would prove, particularly against an individual then, he naturally would have been in favour of a prosecution" $" 152$.

These political relationships have been confirmed by Arthur Norway, Secretary of the Post Office in Ireland, and an eyewitness to the events that led up to the rebellion:"He (Sir Matthew Nathan) had formed the habit of, possibly on the instructions from Mr Birrell, of consulting John Dillon upon every step he took, and viewing everything through the eyes of that old and inveterate rebel". ${ }^{153}$

These assumptions mitigated against any response to the intelligence warnings that the RIC and the DMP were assiduously reporting. The latter organisation demonstrated that it also had the capability to do more that mere surveillance of the Irish Volunteers. The DMP was running two agents ${ }^{154}$ code named 'Chalk' and 'Granite' in the months before the rebellion. Their reports illustrated the degree to which effective police work, with respect to subversive organisations, depended on good intellignece. The DMP built up a detailed picture on the Irish Volunteers. On $24^{\text {th }}$ February 1916 'Granite' reported to ' $G$ ' Division

\footnotetext{
${ }^{149}$ C. Townshend, Easter 1916,The Irish Rebellion, London: Penguin Books 2006 P88.

${ }^{150}$ Ibid, p88

${ }^{151}$ Quoted in F.S.L Lyons ,John Dillon A Biography ,London: Routledge \& Kegan Paul 1968, p366.

${ }^{152}$ The Royal Commission on the Rebellion in Ireland .Minutes of evidence and appendix of documents CD 8311,London:HMSO 1916 p 22.

${ }^{153}$ A.H.Norway, Irish Experiences in War ,in K.Jeffrey ,The GPO and the Easter Rising ,Dublin: Irish Academic Press, 2006 p41.

${ }^{154}$ It is not possible to discern if they were inside or living agents.
} 
detectives that: "The organisers appear to be supplied with plenty of money ,and every effort is being made to win over as many as possible of the members of the National and Redmond Volunteers. He further added that rifles and ammunition are being stored at the residence of Michael O’Hanrahan ,26 Connaught Street ;E. DeValera ,33 Morehampton Terrace; B. O'Connor,1Brendan Terrace, Donnybrook."

On the $22^{\text {nd }}$ March, one month before the rebellion 'Chalk' gave details of a meeting he had attended. One of the speakers was Thomas Mc Donagh ${ }^{156}$.'Chalk' is able to report verbatim extracts of McDonagh's talk to this meeting :'There will be a general mobilization on the next Sunday ,the $2^{\text {nd }}$ April: should any change take place you will be notified by our

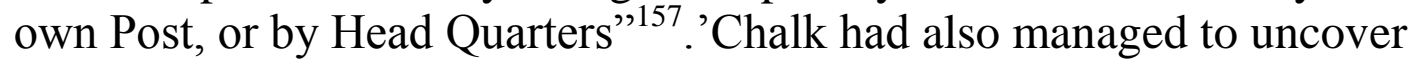
the locations of this communication system :'Harding's, Christ -Church Place; Head Quarters, Dawson Street, and Callan's (address unknown) are some of the places where letters are dealt with" ${ }^{158}$. Perhaps the most startling intelligence that 'Chalk' reveals is that the Irish Volunteers are also in receipt of intelligence from a surprising source: "The Sinn Feiners obtain considerable information, and that as far as can be ascertained, it comes from the Chief Secretary's Office at the Castle" ${ }^{\prime 159}$ The irony is that the cover sheet of this intelligence report indicates that it was seen by the Chief Secretary on the $3^{\text {rd }}$ April 1916! The activities of 'Chalk' continued to provide detailed information on IRB members such a Mc Donagh: "T.Mc Donagh and two other Sinn Feiners were seen to enter the Restaurant in Henry St owned by Mrs W.Power and carrying heavy handbags which they left inside .It is believed that the bags contained ammunition". 160

Augustine Birrell, was not above dissembling with respect to police intelligence. He laid more value on intelligence that underlined the link between Germany and the Irish Volunteers : "I always thought that I was very ignorant of what was going on in the minds, and in the cellars if you like, of the Dublin population. I was always exceedingly nervous about that...... So far as Dublin is concerned, I do not know if Sir Matthew was more in a position than I was to receive these warnings, but I am not

\footnotetext{
155 British Intelligence Reports 1916-1918, Dublin Castle Papers. TNA ,PRO CO904/23

156 Thomas McDonagh was Director of Training of the Irish Volunteers from 1914 .From 1915 he was also a member of the IRB, and from 1916 a member of that organisation's military committee. He was tried and found guilty under the Defence of the Realm Act 1914 and executed by firing squad on the $3^{\text {rd }}$ of May 1916.

${ }^{157}$ Information Respecting The Sinn Feiners ,Detective Dept, $27^{\text {th }}$ March,1916,TNAPRO CO 904/23.

${ }^{158}$ Ibid

${ }^{159} \mathrm{Ibid}$

${ }^{160}$ Information Respecting the Sinn Feiners, Detective Department, DMP $31^{\text {st }}$ March 1916 TNA,PRO CO904/23
} 
conscious of any until towards the end ,the $16^{\text {th }}$ April, when we had the letter from Stafford to General Friend telling us about the ship" ${ }^{\text {"161 }}$.

The policy assumptions continued to exercise an influence on the Birrell-Nathan nexus just two weeks away from the outbreak of the rebellion. They are encapsulated in a letter that Nathan wrote to the Adjutant General of the British Army on the $10^{\text {th }}$ April.: "Though the Irish Volunteers element has been active of late, especially in Dublin, I do not believe that its leaders mean insurrection or that the Volunteers have sufficient arms to make it formidable if the leaders do mean it. The bulk of people are not disaffected"162.

On the $22^{\text {nd }}$ April, three days before the rebellion 'Chalk' reported that: "The Sinn Fein Volunteers are going out for a march on Sunday next, $23^{\text {rd }}$ instant at $4 \mathrm{pm}$.each man to carry three days rations, rifle and ammunition, etc. All men employed in the Civil Service and Government appointments (who are members) to proceed on cycles or walk to a certain place, of which they will be notified later. These men are to leave their rifles and, etc at their respective Depots, and they will be carried by the Transport Section to the place of meeting. This is being done with the object of safeguarding the Government servants from observation by the police" ${ }^{\text {163. }}$.

In the same report a verbatim account was provided of an address given by Thomas McDonagh on the $19^{\text {th }}$ April. This report also illuminated the extent to which the IRB Military Committee, of which he was a member, had used the so called 'Castle' document as evidence of British provocation and a pretext for rebellion.: "Professor McDonagh on issuing the orders on Wednesday night last said: "We are not going out on Friday, but we are going out on Sunday. Boys,some of us may never come back -Mobilisation orders to be issued in due course": .McDonagh further stated that Kelly's statement ${ }^{164}$ relative to the Army was true ,and that it came from friends in the Castle". ${ }^{165}$ This point remains highly contested: "According to Eugene Smith ,the government officer who smuggled the original document on which it was based out of the castle, the document that was publicized was an edited version of an authentic dispatch, outlining the army's plans in the event of the imposition of

\footnotetext{
${ }^{161}$ The Royal Commission on the Rebellion in Ireland, .Minutes of Evidence and Appendix of Documents, London: HMSO 1916 CD 8311 P22.

${ }^{162}$ Nathan to the Adjutant General, Nathan Papers MS 478 Bodleian Library, Oxford University.

${ }^{163}$ Information Respecting Sinn Fein Volunteers ,DMP $22^{\text {nd }}$ April 1916 TNA,PRO CO904/23.

${ }^{164}$ This a reference to a statement read out at a meeting of Dublin City Council by Alderman Kelly

${ }^{165}$ Information Respecting Sinn Fein Volunteers ,DMP,22 ${ }^{\text {nd }}$ April 1916, TNA.PRO CO 904/23
} 
conscription. ${ }^{166, "} Y$ et the Report of the Royal Commission took a completely opposite view, but acknowledged the lethality of its effect: "This document was an entire fabrication .Copies of it found since the outbreak are shown by identification of type to have been printed at Liberty Hall ,the headquarters of the Citizen Army....many copies of this forged document were printed and distributed , and it was widely considered by the people to be genuine, and no doubt led to the belief by members of the Irish Volunteers and Citizen Army that they would shortly be disarmed .This undoubtedly became one of the proximate causes of the outbreak"167

Another piece of intelligence that 'Chalk' provided stated that :"About 700 Martini Rifles were recently landed at Wexford ; and the Motor Car which was seized by the Police at College Green brought 200 military bayonets to Dublin , and the were handed over to "Captain Wafer", who is the Armourer for the Volunteers. I have seen one of these bayonets and it is dated 1899-a short military weapon in a black scabbard , and recently sharpened." 168

This unresolved tension between policy assumptions and the extent to which intelligence was able to influence decisions continued right up to the start of the rebellion at 12 noon on the $24^{\text {th }}$ April .This tension is illustrated by an account given by Lord Wimborne, the Lord Lieutenant of Ireland: "At $7 \mathrm{pm}\left(22^{\text {nd }}\right.$ April $)$ the Under Secretary reported that the prisoner captured in Kerry had been identified as Sir Roger Casement, and that he was on his way to England under a strong guard. I concurred that the Sinn Fein Party had been much dismayed by those events, and the menace of their rising that day could be considered at an end, that a rising was probably contingent on the successful landing of arms and that the prospect of future tranquillity was improved; but when the Under Secretary called at $10 \mathrm{pm}$ I again reverted to the desirability of making arrests in Dublin and urged immediate action" $"$.

These ambiguities, and dilemmas, and the struggle to evaluate the intelligence continued into Sunday $23^{\text {rd }}$ April, the day before the rebellion. At 1030 am Nathan called Lord Wimborne to inform him that the previous night $250 \mathrm{lbs}$ of gelignite had been stolen for a quarry southwest of Dublin and taken to Liberty Hall in Dublin ${ }^{170}$. This theft

\footnotetext{
${ }^{166}$ F. McGarry ,The Rising Ireland :Easter 1916,Oxford: Oxford University Press, 2010 p117.

${ }^{167}$ Royal Commission on the Rebellion in Ireland ,London: HMSO,1916 p12.

${ }^{168}$ Information Respecting Sin Fein Volunteers,DMP,22 ${ }^{\mathrm{ND}}$ April 1916,TNA PRO CO 904/23.

${ }^{169}$ The Royal Commission on the Rebellion in Ireland, Minutes of evidence and appendix of documents CD 8311,London; HMSO ,1916 p36.

${ }^{170}$ This was the headquarters of the Irish Citizen Army.
} 
appeared, initially, to act as a catalyst for action. Nathan proposed to raid Liberty Hall and two other 'Sinn Fein' arsenals whose locations were known to the authorities. These are given as Larkfield Kimmage and Father Matthews Park. In addition, Lord Wimborne urged him 'to put his hand on the ringleaders'. On the same day the Lord Lieutenant wrote what he described as a 'colloquial note' to the Chief Secretary urging him to' write and ginger Nathan'.

On the $23^{\text {rd }}$ of April there were two conferences held by the British authorities. The first at $6 \mathrm{pm}$, and a second at $10 \mathrm{pm}$. At the first meeting Nathan had discussed with two army officers, Colonel Cowan, and Major Owen Lewis the feasibility of organising a raid on Liberty Hall .The advise from these officers was that an artillery piece would be needed to gain entry to Liberty Hall, and that this would have to be brought up from Athlone. The second conference was much more important. It included the Chief Commissioner of the DMP, as well as four army officers, Sir Matthew Nathan and Lord Wimborne. The discussion had a two-fold focus: first gaining entry to Liberty Hall; secondly, securing the arrest of the leadership of the Irish Volunteers. Lord Wimborne had argued for the need to take action: 'I advised the arrest that night of 60 to 100 leaders. I understood the Chief Constable to concur, and to state that immediate arrest was feasible. The Under Secretary demurred on the ground of illegality; he asked what charge could be preferred; that to take action on the ground of hostile association needed the concurrence of the Home Secretary. I argued that the prisoners could be remanded until this concurrence was forthcoming." ${ }^{171}$ With the end of this conference the British state had past up the last opportunity to pre-empt the rebellion. Despite this decision at the end of the second conference Lord Wimborne urged upon Nathan the need for 'immediate and vigorous action'. Even Nathan's interlocutor, John Dillon, in his last letter before the rebellion was beginning to pick rumours of an impending event. With a degree of unintended irony he asked if Nathan had any information about it: "Since I arrived there on Thursday I have heard many disquieting rumours as to mischief brewing .I trust they are without foundation .I wonder whether you have any trustworthy information?"172

The lost opportunity of the meeting on the $23^{\text {rd }}$ April underlined the limitations of intelligence. Political assumptions once they had

\footnotetext{
${ }^{171}$ Royal Commission on the Rebellion. Minutes of evidence and appendix of documents CD 8311,London:HMSO 1916 p37.

172 John Dillon to Sir Matthew Nathan ,23 ${ }^{\text {rd }}$ April 1916 Nathan Papers ,MS 476,Bodleian Library, Oxford University.
} 
become embedded remained immutable in the face of clear intelligence warnings and threatening events.

On the morning of the rebellion, $24^{\text {th }}$ April, the two police forces in Ireland continued to provide reports of surveillance and intelligence based warnings. Lord Wimborne was given critical intelligence by Nathan two hours before the rebellion began : "the Under Secretary called at 10am and reported that at 6am a report from Limerick has arrived that Bailey, who had landed with Casement, had been captured "he is now on trial". He had confessed that the other companion was Monteith, who had escaped and left for Dublin.; that a rising had been planned for that day and Dublin Castle was to be attacked. I urged that the Castle Guard be strengthened, but the Under Secretary demurred." ${ }^{, 173}$ This intelligence had been telegraphed in cipher to the Inspector General of the RIC. It was disseminated beyond Nathan's office. The Headquarters of the British army's Irish Command and the Chief Commissioner of the DMP were informed. Chamberlain also issued orders to all RIC barracks throughout Ireland to be on extra alert and to watch carefully for movements of the Irish Volunteers. ${ }^{174} \mathrm{Grob}-$ Fitzgibbon erroneously argues that: "This was the only solid piece of intelligence the British government received about the Easter rising prior to its beginning". ${ }^{175} \mathrm{He}$ also claimed that Casement's arrest and the interception of the Aud had provided Birrell with a degree re assurance: "The Chief Secretary's Office, however, believed that it was 'unlikely that the intended rising could take place, ${ }^{176}$

Another institution had made extensive preparations based on intelligence warnings that they had received. The Royal Navy, perhaps not surprisingly, acted with alacrity: "We had an old battleship with a marine battalion on board at Milford Haven and they went to Haulbowline Dockyard Queenstown. There were also destroyers from the Grand Fleet and Harwich sent to various Irish ports, and all the SNOs, ${ }^{177}$ at all the patrol bases round Ireland were warned and ready." 178

This evidence casts an instructive light on the assertions made by O'Halpin and McMahon that Captain Hall wanted the rebellion to take

\footnotetext{
${ }^{173}$ Royal Commission on the Rebellion. Minutes of evidence and appendix of documents, CD 8311 London :HMSO 1916 p37.

${ }^{174}$ See B. Grob-Fitzgibbon, Turning Points of the Irish Revolution, London: Palgrave Macmillan,2007p102

${ }^{175}$ Ibid p102

${ }^{176}$ Ibid p102.The source of the quote is taken from Inspector General's Confidential Report ,April 1May 31 1916. TNA CO 904/99:642.

${ }_{177}$ Senior Naval Officers

${ }^{178}$ Recollections Vols 1 and 2 unpublished memoirs of Admiral of the Fleet Sir Henry Oliver,National Maritime Museum OLV 12 p165.
} 
place as it would provide the government a pretext for a policy of repression. ${ }^{179}$ These allegations have been put into perspective by Fitzgibbon: "This counter-conspiratorial myth was, in fact, no more than a traumatic echo of the identical and equally unfounded, myth that the British had somehow manipulated the Irish into the rising of 1798 in order to destroy Irish nationalism and enforce an Act of Union". ${ }^{180}$

It was not until 10.30 am on the $24^{\text {th }}$ April, one and a half hours before the outbreak of the rebellion, that Nathan recognised that the intelligence warnings that had been received rendered the policy assumptions that he had been following untenable. He sent the following telegraph to Birrell: "In view of the definite association of Irish Volunteers with the Enemy now established I agree with the Lord Lieutenant that leaders should be arrested and interned in England. Can this be proceeded with subject to concurrence of the Law Officers, Military authorities and Home office?"181

Less than an hour later the log of the Dublin Metropolitan Police Telephone Messages, all of which were being copied to Dublin Castle, revealed the extent to which events were slipping out of control of the Irish Executive. The initiative now lay with the decisions that had been made by the Military Council of the IRB at 8pm on Easter Sunday when Patrick Pearse sent ,by couriers, a message to the leaders of the Irish Volunteers throughout Ireland saying that the rebellion would start at 12 noon the next day. At 11.20 am a message from E6 AND 78E stated that :"Fifty volunteers now travelled by tram car 167 going in direction of the city." ${ }^{182}$ This report was phoned to three police stations in the city and the Chief Superintendent of ' $G$ ' Division. The next message sent at 11.55am was an attempt to sustain this monitoring. All six divisions of the DMP area were given the following instructions: "Please have three or four cyclists out to watch movement of Volunteers." ${ }^{, 183}$ At the same time a report was received that stated that: "The Volunteers are turning everyone out of Stephens Green Pk and locking up the gates." 184 Liberty Hall was also under surveillance. A message received at 12.20 stated :"The

\footnotetext{
${ }^{179}$ See E. O'Halpin, British Intelligence in Ireland ,1914-1921,from C. Andrew and D. Dilks, The Missing Dimension, Chicago: University of Illinois Press,1984 p60.Also P.Mc Mahon, British Spies and Irish Rebels, Woodbridge Suffolk: The Boydell Press,p21.Although Mc Mahon cites in the endnotes two sets of correspondence between Major Hall and Major Price, and Basil Thompson and Sir Edward Blackwell as evidence of this intent.

${ }^{180}$ C.Fitzgibbon, Out of the Lion's Paw, London: Macdonald \& Co, London ,1969 p63.

181 Telegraph to Birrell ,70 Elm Park Rd .London.24th April 1916.Nathan Papers, MS 476,Bodleian Library, Oxford University.

${ }^{182}$ Nathan Papers, MS 476,Bodleian Library, Oxford University.

${ }^{183}$ Ibid.

${ }^{184}$ Ibid
} 
volunteers are now breaking up at Liberty Hall and going in the direction of Eden Quay. ${ }^{185,}$

As these events were unfolding Nathan's final action was an attempt, to isolate Dublin from the south of Ireland. The assumption being that this would then prevent the spread of any rebellion in Dublin to the rest of the country. To do this he needed the help of Arthur Norway, Secretary of the Post Office. Nathan had phoned him and asked him to come to Dublin Castle on the morning of the $24^{\text {th }}$ April: "He desired me to take immediate steps for denying the use of the Telephone and Telegraph service over large areas of Southern Ireland to all but the military and naval use. I said that was too important a matter to be settled verbally, and I must have it in writing. 'Very well, he said you write what you want and I will sign it'.I was just finishing the necessary order, when a volley of musketry crashed out beneath the window. I looked up .'What is that I asked '.Oh that's probably the long promised attack on the Castle ',cried Nathan."

This attack and the occupation of the GPO was recorded by the DMP Telephone Message log:'12.26pm The Sinn Fein volunteers have

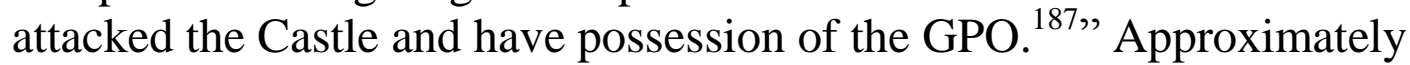
nine minutes later at $12.35 \mathrm{pm}$ the following message was sent out to all stations in the DMP area: "Send to the Castle at once every available man ,also all arms and ammunition". 188 The Royal Commission summarised well the situation that had now come about:" Before any further effective steps could be taken the insurrection had broken out and by noon many portions of the City of Dublin had been simultaneously occupied by rebellious armed forces." 189

On the second day of the rebellion Germany, despite the failure of its attempt to land arms and ammunition in Ireland, still provided support. In accordance with an original request made by Irish Revolutionary Headquarters ${ }^{190}$ it carried out diversionary attacks designed to help the rebels. ${ }^{191}$ On the 25th of April, elements of the German High Seas Fleet bombarded the Kent town of Lowestoft. This bombardment lasted only

\footnotetext{
185 Ibid

${ }^{186}$ A.H. Norway ,Irish Experiences in War ,from K. Jeffrey, The GPO and the Easter Rising, Dublin: Irish Academic Press ,2006 p40

${ }^{187}$ Nathan Papers, MS 476,Bodleian Library ,Oxford University.

${ }^{188}$ Ibid

${ }^{189}$ Royal Commission on the Rebellion in Ireland CD8279 London :HMSO 1916 p12.

${ }^{190}$ See p16.

${ }^{191}$ William James in this biography of Hall makes the following claim.: "The Germans agreed to arrange a demonstration by airship and naval attack to divert attention from the landing of arms" W. James, The Eyes of the Navy :A Biographical Study of Admiral Sir Reginald Hall, London :Methuen,1955 p110.
} 
15 minutes, but destroyed 200 houses. It was driven off by a naval force consisting of the $5^{\text {th }}$ Light Cruiser Squadron under Commodore Tyrwitt. ${ }^{192}$ Warning of this diversion was a product of a signals intelligence from Room 40: "The Grand Fleet was hard at work refuelling when at 4.0 in the afternoon Admiral Jellicoe received from Whitehall news of the gravest import. A rebellion had broken out in Ireland ,Sinn Fein was in possession of Dublin , the High Seas Fleet appeared to be moving , and there was reason to believe that the Germans intended to support the insurgents with a demonstration against our coast". 193

The first public acknowledgement, by the British authorities in Ireland, of the involvement of the Imperial German Government in these events came on the first day of the rebellion. The wording of a proclamation issued by the Lord Lieutenant of Ireland ,Lord Wimbourne was explicit: "Whereras an attempt, instigated and designed by the foreign enemies of our King and Country to incite rebellion in Ireland , and thus endanger the safety of the United Kingdom, has been made by a reckless though small body of men, who have been guilty of insurrectionary acts". ${ }^{194}$

Dublin was engulfed in fighting until the $29^{\text {th }}$ April when the Patrick Pearse, the self styled 'Commander-in- Chief of the Army of the Republic' ordered a general surrender to British Forces. The cost in terms of lives amounted to 116 British soldiers and officers, 13 members of the RIC, three members of the DMP. There were also 318 insurgents and civilians killed. ${ }^{195}$ In addition, the destruction in the centre of Dublin had been enormous: "The Chief of the Dublin Fire Brigade reported that over 200 buildings had been destroyed during the rising , and estimated the value of all that had been destroyed at to be in the region of $£ 2,500,000$ ". ${ }^{196}$

\section{CONCLUSIONS}

At the beginning of this article it was stated that the bulk of the literature on the Irish rebellion of 1916 supported the teleological narrative of intelligence failure. The anatomical structure of this claim has three aspects. First the dissemination of and access to signals intelligence obtained by the Royal Navy was kept isolated from both the

\footnotetext{
${ }^{192}$ For a detailed insight to the dispositions of the German and British naval forces see J.S. Corbett, Naval Operations , London: Longman and Green \& Co,1923, Vol 3 (Maps) numbers 14 and 15.

${ }^{193}$ Ibid Vol 3 p300.

${ }^{194}$ TNA CO904/23/2B:17 quoted in B. Grob-Fitzgibbon, Turning Points of the Irish Revolution, London: Palgrave Macmillan, 207 p212.

${ }^{195}$ For the full extent of the casualties see Ibid p108.

${ }^{196}$ Ibid p108
} 
British Cabinet and the Irish Executive. Instead the Director of Naval Intelligence, Captain Reginald Hall manipulated this intelligence for the purpose of ensuring a policy of repression was enacted by the British authorities once the rebellion had begun. Secondly, the Admiralty's human intelligence resources in Ireland were limited in focus to such concerns as the loyalty of dockyard employees. Finally, the co-operation of the mobile and stable forces of law and order was poor, and there was a failure to evaluate correctly the intelligence that had been obtained.

The article provides a number of new insights to the extent of the dissemination of intelligence prior to the rebellion. The most significant is the fact that the Cabinet ${ }^{197}$ and Asquith, the then Prime Minister, ${ }^{198}$ were both in receipt of intelligence warnings that came from Room 40 before the rebellion broke out. There is also evidence to show that Nathan was in receipt of intelligence that made the link between the Imperial German Government and the IRB seven days before the rebellion. ${ }^{199}$ The Royal Navy were running a human intelligence network inside Ireland that had been in part responsible for the arrest of Sir Roger Casement. ${ }^{200}$ The Admiralty was not isolated from intelligence operations in Ireland.

These insights focus attention on two related questions that were raised at the beginning of this article about the extent that there was a failure of response, and the degree to which the assumptions of key policy makers were responsible for the ignoring of these warnings. The failure of response by Birrell and his Under Secretary Nathan was sustained to the morning upon which the rebellion broke out: "Early on the $24^{\text {th }}$ the Chief Secretary's concurrence was asked for in the proposed arrest and internment in England of the hostile leaders in view of their definite association with the enemy having been established."201

This failure of response can only be understood in the context of the political assumptions held by Birrell. Writing in 1937, he was candid about them : "I had seen my own policy clearly from the first. It was to pave the way for Home Rule (on more or less Gladstonian lines), and to do all that in me lay to make any other solution of the problem impossible. In nine years of patronage, if not power, it was possible to do

\footnotetext{
${ }^{197}$ See p2

${ }^{198}$ See p 21

${ }^{199}$ See p25

${ }^{200}$ See p24.

${ }^{201}$ The Royal Commission on the Rebellion in Ireland, CD 8279 London: HMSO,1916
} 
a good deal in that direction." 202 A direct consequence of this was the unwillingness to enforce the basic parameters of governance:

"The main cause of the of the rebellion appears to be that lawlessness was allowed to grow up unchecked, and that Ireland for several years past has been administered on the principle that it was safer and more expedient to leave the law in abeyance if collision with any faction of the Irish people could thereby be avoided. Such a policy is the negation of that cardinal rule of Government which demands that enforcement of law and the preservation of order should always be independent of political expediency." ${ }^{203}$ This was also the view General Maxwell, the British General sent to deal with the rebellion. He wrote to his wife on the $4^{\text {th }}$ May 1916.:"It is the government as a whole that are to blame. Ever since they winked at Ulster breaking the law they have been in difficulties and have hoped that something would turn up ....Wait and see.Well, we waited and now see the result ,viz rebellion and loss of life."204

Another set of questions that were posed at the beginning of this article was the nature of the intelligence institutions on which the British state both in London and Dublin depended. Linked to this was the manner in which the intelligence was processed, and the quality of the intelligence that British policy makers had access to. One of the key findings of this article is the fact that the British state had access to both signals and human intelligence sources both inside and outside Ireland. The Royal Commission takes what could be described as an 'Ireland only' approach, that focused exclusively on the intelligence performance of the two police forces: "We are satisfied that Sir Neville Chamberlain ,the Inspector-General of the Royal Irish Constabulary, and Colonel Edgeworth-Johnstone ,Chief Commissioner of the Dublin Metropolitan Police, required their subordinates to furnish, and did receive from their subordinates, full and exact reports as to the nature, progress and aims of the various armed associations in Ireland. From these sources the Government had abundant material on which they could have acted many months before the leaders themselves contemplated any actual rising. For the conduct zeal and loyalty of the Royal Irish Constabulary and the Dublin Metropolitan Police we have nothing but praise"205.This unbalanced approach is underlined by a question that was posed by the Chairman of the Royal Commission to Nathan on the $18^{\text {th }}$ May 1916:"Could you kindly tell us what organisation exists in Ireland for

\footnotetext{
${ }^{202}$ A. Birrell, Things Past Redress ,London: Faber and Faber,1937 p212.

${ }^{203}$ Royal Commission on the Rebellion In Ireland, CD8279, London: HMSO 1916.p12.

${ }^{204}$ Quoted in M. Foy and B. Barton, The Easter Rising ,Stroud Gloucestershire: Sutton Publishing, 1999,p233.

${ }^{205}$ Royal Commission on the Rebellion in Ireland, CD 8279 London: HMSO ,1916 p13.
} 
obtaining information about what is going on in the country and outside it as much as possible?"206

Despite access to timely and accurate intelligence, Nathan discounted, and indeed denied, the quality of the intelligence that he had been in receipt of: "Until three days before the rebellion there had been no definite proof of any connection between the anti-British party in Ireland and the foreign enemy." ${ }^{207}$ Nathan refused to sanction, on the grounds of legality and the lack of concurrence of the Home Secretary, the arrest of between 60 to 100 of the leaders of the Irish Volunteers. This was despite police advice that such an operation was feasible. ${ }^{208}$ It can be argued that it would have seriously undermined the ability of the Military Council of the IRB to have enacted the planned rebellion on Easter Monday. Nathan discounted the possibility of any intelligence led action that could have prevented the rebellion from taking place: "There seems to have been a meeting of the leaders in Dublin on Saturday or Sunday ,when it was decided (it is said by a majority of one)to start an insurrection on Monday. Had information been obtained of this, the movable column would no doubt have been ordered from the Curragh.....but whether this would have stopped the wild attempt is doubtful". ${ }^{209}$

Nathan like his boss Birrell had a focus on a policy assumption. This assertion is not new. O'Broin underscored a similar point over forty years ago: "Sir Matthew acted on grounds of policy rather than on grounds of insufficient evidence". ${ }^{210}$ It illustrates a generic problem that exists in the relationship between policy and intelligence: "At the point where intelligence meets policy, leaders sometimes reject warnings." 211 The assumptions of Birrell and Nathan illuminate the degree that intelligence warnings and responses from policy makers are driven by a timeline that is dynamic and there is a point whereby a response to an anticipated attack or rebellion has a marginal utility:" The issue in most cases is not a yes-or -no question of whether there is a warning or response; rather the issue is how much warning there is and how soon response begins."212

\footnotetext{
${ }^{206}$ Ibid Minutes of evidence and appendix of documents. P10

${ }^{207}$ Statement by Sir Matthew Nathan to the Royal Commission on the Rebellion in Ireland ,Minutes of evidence and appendix of documents, $18^{\text {th }}$ May 1916, CD 8311,London:HMSO 1916 P7.

${ }^{208}$ See p32-33

${ }^{209}$ Statement by Sir Matthew Nathan to the Royal Commission on the Rebellion in Ireland ,Minutes of evidence and appendix of documents, $18^{\text {th }}$ May 1916, CD 8311,London:HMSO 1916 p10.

${ }^{210}$ L.O'Broin, Dublin Castle and The 1916 Rising ,London: Sidgwick and Jackson,1966,p159.

${ }^{211}$ M. Herman, Intelligence Power in Peace and War, Cambridge: Cambridge University Press, 1996, p225.

${ }^{212}$ R. K. Betts, Analysis ,War and Decision: Why Intelligence Failures are Inevitable, World Politics, Vol ?No? 1978 p91.
} 
An insight to this phenomenon was given by Arthur Norway: "Sir Matthew, whose action had prevented the arrest of any ring leaders while there was still time, was shaken and bewildered at the moment of the outbreak, it is little wonder. His reputation was gone. His counsellor (John Dillon) had betrayed him. He has failed to guard England from added danger. I do him the justice of believing the perception to have been very bitter to him." ${ }^{, 13}$

Writing 21 years after the rebellion Birrell demonstrated an inability to come to terms with the failure of response that he had been responsible for: "Labour troubles, fostered by the state of the slums of Dublin, which might be called a disgrace to Civilisation and Christianity, did such words now days possess any particular significance, and formented also by exceedingly bad labour conditions, had a great deal to do with the outbreak." 214

The final propositions that examined were assessments of the accuracy of the intelligence that the Irish Executive and the British Government had received, and the extent to which a response became conflated with the political relationship that Birrell and Nathan had with members of the Irish Parliamentary Party. The conclusions reached by the Royal Commission were insightful with respect to both of these aspects:

"It appears to us that reluctance was shown by the Irish Government to repress by prosecution written and spoken seditious utterances, and to suppress the drilling and manoeuvring of armed forces known to be under the control of men who were not only declaring their hostility to Your Majesty's Government and their readiness to welcome and assist Your Majesty's enemies. This reluctance was largely prompted by the pressure brought to bear by the Parliamentary representatives of the Irish people, and in Ireland itself there developed a widespread belief that no repressive measures would be undertaken by the Government against sedition. This led to a rapid increase of preparations for insurrection and was the immediate cause of the recent outbreak." ${ }^{215}$

The Irish rebellion of 1916 raises two issues which have an enduring significance for the study of intelligence. The first is what could be described as the inability of intelligence to limit uncertainty. Irish

\footnotetext{
${ }^{213}$ A.H. Norway, Irish Experiences in War ,from K. Jeffery ,The GPO and the Easter Rising ,Dublin: Irish Academic Press 2006 p45.

${ }^{214}$ A. Birrell, Things Past Redress, London :Faber and Faber,1937p219.

${ }^{215}$ Royal Commission on the Rebellion In Ireland ,CD 8279,London :HMSO ,1916 p13.
} 
historians when writing about the rebellion have assumed a perfectibility of intelligence by the British state: "The principal charge against the Castle authorities- remain-that they were remarkably ignorant of where power lay in the revolutionary movement and what the younger, fanatical leaders intended." 216 However, intelligence has got the ability to help manage uncertainty. The scope of what was known about the impending rebellion, both from signals intelligence and human intelligence sources, had been conveyed to the Prime Minister, the Cabinet, Birrell and Nathan. Yet they were all prisoners, to varying degrees, of a policy assumption which had as its twin focus the need to sustain recruiting and implementation of Home Rule after the end of the war. Asquith, writing twelve years after the rebellion, revealed his assumptions. It was focused on the problem of Ulster. There was no recognition of the implications for Irish politics of organisations that could blend propaganda and political violence: "The abortive Sinn Fein rising at Easter ,1916 was followed by a sincere but unsuccessful effort on my part and that of my colleagues in Government to arrive at a settlement of the Ulster difficulty. $" 217$

The second issue is the desire for certainty. At a basic level people search for order and fulsome explanations rather than accept that there are certain things they cannot know. Pillar argues that this tendency has a particular resonance for policy makers: "The craving for certainty is even stronger with policy makers. They want to accomplish the policy agenda with which they came to office; they do not want to be diverted by the unexpected. The wish becomes father to the belief." 218

Betts has argued that these two enduring issues could be resolved by the development of a normative theory of intelligence. ${ }^{219}$ This would enable an understanding of how intelligence structures are subject to failures of warning, or why policy makers fail to respond until it is too late. There are inherent limitations as far as normative theory is concerned: "Development of a normative theory of intelligence has been inhibited because the lessons of hindsight do not guarantee improvement in foresight." ${ }^{220}$ One of the ways that the problem of intelligence failure and lack of response has been conceptualized is by what has been described as the paradoxes of perception. ${ }^{221}$. The paradox that confronted

\footnotetext{
${ }^{216}$ F.S.L Lyons, John Dillon A Biography, London: Routledge and Kegan Paul ,1968 p368.

${ }^{217}$ H. Asquith, Memories and Reflections, London: Cassell 1928, Vol 2 p181.

${ }^{218}$ P.R. Pillar, Intelligence and United States Foreign Policy, New York: Columbia University Press 2011 p333.

${ }^{219}$ Se R.K. Betts, Analysis ,War and Decision: Why Intelligence Failures Are Inevitable, World Politics Vol No 1978 p62.

${ }^{220}$ Ibid p62

${ }^{221}$ Ibidp63
} 
the British Cabinet and members of the Irish Executive was a dilemma that they proved incapable of resolving. The enforcement of the law and the preservation of order became subservient to the political expediency of sustaining an unworkable idea- Home Rule for Ireland .This was juxtaposed with consistent intelligence warnings from both human and signals intelligence sources that Germany, Britain's continental enemy, in an alliance with the physical force element of Irish Republicanism, intended to turn a part of the United Kingdom into a theatre of political warfare. 